NBER WORKING PAPER SERIES

\title{
STUDENT LEARNING IN ONLINE COLLEGE PROGRAMS
}

\author{
Stephanie Riegg Cellini \\ Hernando Grueso \\ Working Paper 28552 \\ http://www.nber.org/papers/w28552
NATIONAL BUREAU OF ECONOMIC RESEARCH
1050 Massachusetts Avenue
Cambridge, MA 02138
March 2021

We would like to thank Dylan Conger, Maria Ferreyra, Angelica Sanchez Diaz, Sebastian Gallegos, Di Xu, and seminar participants at GWU, the DC Economics of Education Working Group, and AEFP for helpful comments. We thank Cesar Villanueva and Lizeth Gonzalez for excellent research assistance. We appreciate the support of a Trachtenberg School Faculty Research Fellowship grant and thank the Colombian Institute for the Evaluation of Education (ICFES) for sharing the data that made this research possible. The views expressed herein are those of the authors and do not necessarily reflect the views of the National Bureau of Economic Research.

NBER working papers are circulated for discussion and comment purposes. They have not been peer-reviewed or been subject to the review by the NBER Board of Directors that accompanies official NBER publications.

(C) 2021 by Stephanie Riegg Cellini and Hernando Grueso. All rights reserved. Short sections of text, not to exceed two paragraphs, may be quoted without explicit permission provided that full credit, including $\left({ }^{\circ}\right.$ notice, is given to the source. 
Student Learning in Online College Programs

Stephanie Riegg Cellini and Hernando Grueso

NBER Working Paper No. 28552

March 2021

JEL No. I21,I23,O15

\begin{abstract}
$\underline{\text { ABSTRACT }}$
We draw on administrative data from the country of Colombia to assess differences in student learning in online and traditional on-campus college programs. The Colombian context is uniquely suited to study this topic, as students take a compulsory exit examination at the end of their studies. We can therefore directly compare performance on the exit exam for students in online and on-campus programs both across and within institutions, degrees, and majors. Using inverse probability weighting methods based on a rich set of background characteristics coupled with institution-degree-major fixed effects, our results suggest that bachelor's degree students in online programs perform worse on nearly all test score measures (including math, reading, writing, and English) relative to their counterparts in on-campus programs. Results for shorter technical certificates are more mixed. While online students perform significantly worse than oncampus students on exit exams in private institutions, they perform better in SENA - the main public vocational institution in the country.
\end{abstract}

Stephanie Riegg Cellini

Trachtenberg School of Public Policy

and Public Administration

George Washington University

80521 st Street, NW, Suite 601

Washington, DC 20052

and NBER

scellini@gwu.edu

Hernando Grueso

Trachtenberg School of Public Policy

and Public Administration

George Washington University

805 21st Street, NW, Suite 601

Washington, DC 20052

hgrueso@gwu.edu 


\section{Introduction}

In 2020, as the global coronavirus pandemic shut down college campuses around the world, a record number of postsecondary students were pushed into virtual education—at least temporarily. In the early months of the pandemic, estimates surfaced that at least 14 million U.S. students went online (Hess 2020). More recent data finds a marked increase in enrollment in primarily online institutions in the fall of 2020 over the previous year, while enrollment in more traditional campus-based public institutions has declined (National Student Clearinghouse 2020). In light of these dramatic changes, it is more important than ever to evaluate the quality of online education.

The expansion of online college programming is not simply a product of the pandemic. In 2018, more than one-third (35 percent) of U.S. college students took at least one course online and 17 percent were enrolled exclusively online (NCES 2020). Students in all sectors-public, nonprofit, and for-profit-take online courses in the United States and around the world, but the for-profit sector is by far the leader in online programming. Pre-pandemic, $72 \%$ of students in four-year for-profit colleges were attending exclusively online, compared to just $12 \%$ of students in four-year public colleges in the U.S. (NCES 2020). International for-profit chains offering online programs have increased their footprint worldwide. The growth has been particularly strong in Latin America, where, for many years, online institutions have been tapping into the increasing demand for postsecondary education as high school completion rates rise.

In this paper, we draw on data from the country of Colombia to assess student learning in online versus in-person college programs. The Colombian context is uniquely 
suited to study this question, as students take a compulsory college exit examination at the end of their studies. We can therefore directly compare student performance on the exit exam for students in online and campus-based programs within the same institution, degree, and even major. We believe we are among the first to use standardized test scores to assess student learning in online postsecondary programs.

Our main estimates rely on inverse probability weighting to compare students who are similar on a rich set of background characteristics, including $11^{\text {th }}$ grade test scores and parental socioeconomic status. We compare online students with matched students within the same college, degree, and major taking classes face-to-face using a comprehensive set of institution-degree-major fixed effects. We supplement this analysis with an instrumental variables strategy based on the timing of broadband Internet rollout in the country. We draw on administrative data from about 500,000 students exiting technical certificate and bachelor's degree programs between 2012 and 2017. We believe we are the first to explore the learning outcomes of students in short-term technical programs in Colombia, including those in the largest public institution in the country, SENA.

Research on online education in the U.S. has generally found that while online programs expand access to education, students taking classes online perform worse than their on-campus counterparts on outcomes ranging from employment, earnings, employer callbacks, and grades. Our data allow us to assess student learning and skill-level more directly than previous studies by comparing exam performance in quantitative analysis, reading, and writing. 
In general, we find that online students perform worse on exit exams than oncampus students. Across most institutions, degrees, and fields, we find that online students have significantly lower test scores at the time of college exit than their matched oncampus peers. Results are consistent across math, reading, and writing and we find particularly large negative effects for online students in bachelor's degree programs and private technical institutions. In a notable exception, in the largest public vocational institution, SENA (Servicio Nacional de Aprendizaje), online technical students have higher exit exam scores than their on-campus counterparts. Our results suggest substantial heterogeneity across institutions in the quality of online programming, although we caution that we cannot rule out some forms of selection.

The results of our study are not only important for assessing the quality of online education generally, but also for assessing the welfare implications of Coronavirus-related shutdowns and policies that encourage online coursetaking around the world. In Colombia, as elsewhere, policymakers are grappling with policies that would promote and regulate private postsecondary education. Although private colleges in Colombia are not allowed to officially operate as "for-profit" many international chains and nonprofits operate similarly, eliciting calls for further regulation from policymakers in recent years. ${ }^{1}$ Further, current debates in the country center around taxpayer-funded scholarship programs to expand access to higher education for low-income students. Ser Pilo Paga was the first such program created in 2015. It was intended to cover full tuition and living expenses of

\footnotetext{
${ }^{1}$ For example, Congresswoman Claudia López, called attention to the issue of international for-profit chains (e.g., Laureate Education, Apollo, and Whitney) acquiring existing universities in Colombia. López provided a list of non-profit universities in partnerships with international for-profit chains that she contends were behaving as for-profits (López, 2014 February).
} 
outstanding low-income students supporting their access to higher education. Proponents argued that the program allow talented students to afford high-quality postsecondary education, while opponents contended that scholarships benefitted a small minority of low-income students who attended private universities of questionable quality. These debates eventually led to the replacement of Ser Pilo Paga in 2019. The new program, Generación E covers full tuition at public universities, but only half of tuition at private institutions. By shedding light on the quality of various postsecondary options, this study can inform the design of aid programs in Colombia and other developing countries.

\section{Background}

The Colombian higher education system is typically grouped into four levels of higher education institutions offering different types of degrees. Universities are research institutions authorized to offer bachelor's degrees and graduate academic programs. University institutions are those authorized to offer bachelor's degrees and a degree called "specialization," that provides advanced knowledge in a specific area but is considered below the master's level. Technological institutions are those authorized to offer technologist degrees ("technológico") with a scientific basis, which typically take about three years. Finally, professional technical institutions, are those authorized to offer technical degrees ("técnico profesional"), which are short-cycle programs lasting about two years and provide specific training for jobs without a scientific basis (OECD 2012). There are both private and public institutions at each level. In general, there is no clear difference in terms of quality or reputation between private and public higher education institutions in Colombia, and tuition varies across levels and sector. Wealthier families tend to choose 
more expensive private options while lower-income families tend to choose public institutions with lower tuition.

As in other Latin American countries, enrollment in higher education has expanded dramatically in Colombia in recent decades-doubling between 2000 and 2013 (Carranza and Ferreyra 2019). Bachelor's degree programs increased substantially during that time period, adding about 600,000 students and much of the growth was due to the addition of roughly 1,500 new programs that were concentrated in low-end private institutions (Ferreyra et al. 2017).

Short-cycle programs have also expanded-largely due to the expansion of the National Training Service, known as SENA (Servicio Nacional de Aprendizaje). From 2005 to 2013, SENA added about 300,000 new students to the short-cycle market (Ferreyra et al. 2017). As we describe in detail below, many of these programs were offered fully or partially online. In fact, online education has become quite common in Colombia at all levels of postsecondary education. According to the Colombian Ministry of Education, about 359,020 students were enrolled in some form of hybrid or fully-online higher education in 2017, accounting for roughly $15 \%$ of the total number of students enrolled in higher education in the country (Colombian National Higher Education Information System SNIES, 2020).

SENA is a tuition-free public institution and by far the largest provider of vocational training and online short-cycle programs in Colombia, enrolling nearly half of all technical students. There is just one other public institution that offers online technical education in the Colombia, UNAD (Open and Distance Learning National University) with just 1,500 
students, but—unlike SENA—it charges tuition. ${ }^{2}$ As shown in Appendix Table $1 \mathrm{~A}$, there are 61 private providers of vocational programs in Colombia offering both online and inperson programs and all of them are much smaller than SENA. ${ }^{3}$

SENA was created in 1957 with the goal of improving the skills of the national workforce and offering programs completely free of charge (SENA 2020). In 1977, SENA started offering distance learning courses by mail that did not require in-person interaction between students and instructors (Salazar-Ramos \& Melo-Cortés 2013). Virtual distance learning began at SENA in 2003 and fully online degree programs were introduced in 2014. Enrollment in SENA's online courses expanded from 28.8 thousand to 5.6 million $^{4}$ between 2003 and 2012 (Cadena-Cruz 2017).

SENA is completely free of charge which makes it appealing to low-income students, however, high dropout rates are a key concern of administrators. According to interviews conducted with SENA staff, dropout rates in their online degrees are around 60\%. Despite this high rate, it is not too different from the national dropout rate among technical students of 53\% (SPADIES 2017). Online and on-campus programs do not appear differ in their requirements nor their application process. To enroll in SENA, students follow an application process that is similar to those of competitor institutions. The steps include the submission of a high school diploma and proof of Colombian citizenship or residence. In

\footnotetext{
${ }^{2}$ Because it charges tuition, we include UNAD with the private institutions in our main analyses. Results are unchanged if we include it with SENA in the group of publics (see Appendix Table A7).

${ }^{3}$ See Appendix Table A1 for details on the distribution of online students across institutions.

${ }^{4}$ This total is includes enrollment in independent online courses offered by SENA, not just the online programs we study.
} 
addition, applicants must pass a set of short quizzes. ${ }^{5}$ The quizzes assess simple reasoning and citizenship. They seem to be intended to add a small time cost to enrollment to dissuade frivolous or unintentional sign-ups. ${ }^{6}$

\section{Related Literature}

\section{Higher Education in Colombia}

Research on higher education in Colombia has become more prevalent as data from the Ministry of Education has become increasingly available in recent years. MacLeod et al. (2015) draw on the rollout of the college exit exams in 2009 to illustrate the role that college reputation in plays college choice and sorting. Domingue et al. (2017) ask whether the same college exit exams should be administered to students in universities and technical institutions. Using item response theory analysis, they find that the original Colombian college exit exam (known as the Saber Pro, described further below) has slightly reduced reliability among technical students relative to university students. However, they also find that the test performs adequately for each group when analyzed separately.

Most relevant to this study, Riehl, Saavedra, and Urquiola (2017) consider the relationship between learning (based on college exit exam scores, similar to those used here) and earnings. They find that while learning and earnings are correlated, learning measures are less influenced by socioeconomic status and tuition than earnings measures.

\footnotetext{
${ }^{5}$ SENA website: http://portal.senasofiaplus.edu.co/index.php/ayudas. This process is similar to that of other institutions, such as the Politécnico Grancolombiano, which requires copy of an official identification, high school diploma, and results of the high school standardized test, Saber 11:

https://www.poli.edu.co/content/proceso-de-admision

${ }^{6}$ Based on one author's application, quizzes are 25 minutes long and involve 20 multiple choice questions (e.g., "What should you do if your neighbor is throwing loud parties every night?")
} 
They further suggest that the value-added exit exam scores that they study may go further in isolating the college's contribution to human capital than earnings measures.

Riehl, Saavedra, and Urquiola also find interesting differences for public and private institutions: private colleges outperform publics on earnings, but publics outperform private colleges on learning. When it comes to critical thinking and persuasive writing in particular, Saavedra and Saavedra (2011) find that private institutions increase test scores more than public institutions. Several other studies have also examined the question of differences in student outcomes for public and private sector students in Colombia (Sarmiento and Sandoval 2008, Gil et al. 2013; Gomez 2015, Guarín et al. 2016). They find somewhat mixed results ranging from much higher test scores and earnings for public sector students to no differences across sectors.

Carranza and Ferreyra (2019) decompose the expansion of higher education enrollment in Colombia between 2000 and 2013. They find that only a small portionroughly one-quarter-of enrollment growth is attributable to demand-side factors. Most of the growth is related to the supply-side expansions of short-cycle programs, new bachelor's programs, and private institutions catering to low-income students. These patterns are strikingly similar to the growth of the for-profit sector in American higher education over the same time period (Deming, Goldin, and Katz 2012).

Focusing on quality, Camacho et al. (2017) evaluate the difference between new bachelor's degree programs (started since 2000) in Colombia and more established programs. After matching on student characteristics, the authors find that students in newer programs have lower wages and test scores, but this result may be driven by the relatively lower-paying fields of study that newer programs are concentrated in. 
We know of only a handful of studies that assess student outcomes in online education in Colombia and none address issues of selection. Rodríguez et al. (2014) examine bachelor's degree students' test scores in one year and find a clear advantage of on-campus over online programs. Ortiz et al. (2015) compare online and on-campus student business administration students in two similar universities. They find lower performance of online students on quantitative and English exams, but no significant differences in writing. They report larger differences in student outcomes across institutions, than across modes of study. A similar study looking at the scores of bachelor's business administration students within a single university between 2013 and 2015 finds no significant differences between online versus on-campus students (Boada and Cardona 2017).

\section{Online Education in the United States}

The U.S. literature has gone further in identifying the causal effects of online courses on student outcomes and on the market for higher education more generally. Employing an instrumental variables design based on Internet penetration, Deming, Lovenheim, and Patterson (2016) assess the competitive impacts of online program availability on traditional campus-based colleges. They find evidence of enrollment declines and increased instructional spending among non-selective private and local public institutions, in response to competitive pressure from online programs. Looking at a public graduate program, Goodman et al. (2017) finds that online education expands access to education, rather than shifting students from other educational options. 
To assess student outcomes in online courses, several studies randomly assign students to either an online or in-person format of a single college course and examine performance on final exams or course grades (Figlio et al. 2013, Alpert et al. 2016, Bowen et al. 2014, Joyce et al. 2015). Others draw on larger samples of students in observational studies, implementing fixed effects, instrumental variables, or other methods to address selection (Hart 2018, Bettinger et al. 2017, Xu and Jaggars 2014, Hoxby 2015, Krieg and Henson 2016). Across both the randomized and observational studies, results are consistent: online coursework generally yields worse student performance. Negative effects of online coursetaking are particularly pronounced for less-academically prepared students.

This paper contributes to the literature in several ways. First, we assess whether the disappointing learning outcomes of students taking online courses hold outside of the U.S. context. Second, we are able to draw on large-scale administrative data on student outcomes for an entire country, rather than a single university or system, as is typical in the literature. The Colombian data allow us to push the literature further in assessing whether the impacts of online coursetaking vary by sector (private vs. public), institution-type (university vs. technical), degree (BA vs. short-cycle technical), and major (business vs. health) as well as within specific institution-degree-major combinations. Third, our data rely on a compulsory exam used to measure students' skills at the end of college and therefore get around questions surrounding the subjectivity of course grades and selection into subsequent coursetaking, as in other studies. Fourth, we have rich background dataincluding high school test scores, making an inverse probability weighting strategy possible. Finally, we believe we are the first to use the newly-available SaberTyT data to 
measure the learning outcomes of students in technical programs. With these data, we can for the first time evaluate the test scores of students in SENA, the largest public technical institution in Colombia. In light of the results of the U.S. studies, we anticipate that students in technical programs may be the most likely to be harmed by online coursework.

\section{Data}

The Colombian Institute for the Evaluation of Education (ICFES) is a public agency within the Ministry of Education that administers standardized tests to measure the quality of education in Colombia. ICFES provides open access to test score data to promote education research that can inform public policy in the country. ${ }^{7}$ In this paper, we draw on three standardized tests taken at the end of college and high school: Saber Pro, Saber TyT, and Saber 11.

Saber Pro, previously known as ECAES (until 2012), is an exit exam required to complete bachelor's degree programs in Colombia. Since 2009, nationally standardized exit exams have been mandatory for graduation (Colombian Law 1324, 2009). Our data include information on all students in the country who graduated with a bachelor's degree between 2012 and 2016. ${ }^{8}$ There are five mandatory general modules in the exam: 1) critical reading, 2) quantitative reasoning, 3) civics, 4) writing and 5) English. These five modules include a total of 150 multiple-choice questions and a short essay, to be answered in a time frame 4 hours and 40 minutes. ${ }^{9}$

\footnotetext{
7 The ICFES website: http://www.icfes.gov.co provides most of the information in this section.

${ }^{8}$ Early rounds of the Saber Pro were reported to have psychometric reliability problems but these were addressed in 2009 when the methodology was updated (OECD et al 2012).

${ }^{9}$ There are 40 other modules (not considered here) that students may take in their specific fields of expertise (e.g., medicine).
} 
The main purpose of Saber Pro is to monitor the quality of higher education in Colombia and its results do not have any other practical use. There are some concerns about the meaning of exam scores, since students have little incentive to perform well since SABER scores are not considered in graduate school application processes. However, there are other incentives for test takers: some employers in the country request Saber Pro scores as part of their selection processes and the Colombian government forgives the student loans of low-income students who earn the highest score (OECD 2012).

Saber TyT was created in 2016 to test general and specific knowledge obtained by students in technological and professional technical institutions. Our data include all students-about 300,000 in total-completing programs in 2016 and 2017. This test includes the same general modules available in Saber Pro: quantitative analysis, reading, writing, English, and civics, along with several specific modules in technical areas. ${ }^{10}$ The test is particularly helpful for assessing student outcomes in SENA.

To identify online students in the Saber Pro and TyT data sets, we rely on a student's self-reported method of study, reported at the time of their exit exams. We code students as "online" if they self-report their study method as either "virtual" or "distance" (rather than "traditional"). According to Colombian law (Decree 1075 of 2015, Article 2.6.4.5), virtual programs are those conducted at least $80 \%$ online, while those with lower proportions of online learning should be designated "distance learning."11 In practice, however, the distinction between virtual and distance does not vary materially, as some schools (and

\footnotetext{
${ }^{10}$ Specific modules include (i) machinery assembly, maintenance and operation, (ii) hardware and software maintenance and installation, and (iii) health promotion and disease prevention.

11 These are known as "hybrid" programs in other contexts.
} 
students) appear to use the term "virtual" and others use the term "distance" for programs where the majority of learning occurs online. Administrators at SENA report that even though they call some programs "distance learning," they no longer use paper correspondence and most of these programs are currently more than $70 \%$ online with some in-person components. ${ }^{12}$ For example, SENA offers a tour guide program that is almost completely online, but it requires a handful of field trips to places like museums and national parks. Most of our analyses combine distance education and virtual programs due to power concerns. ${ }^{13}$

A key limitation of both the Saber TyT and Saber Pro data is that we can only observe scores for students who complete their degree programs. This limitation raises important concerns over both attrition and selection. Differences in attrition for online and oncampus programs may be particularly concerning, but unfortunately, we cannot observe initial enrollment or dropout decisions of the students in our sample. As noted above, SENA's dropout rate is roughly $60 \%$, which is fairly close to the $53 \%$ reported for all technical students in the country, but we do not have data that disaggregates rates for online and on-campus students. Differential selection among online and on-campus students is another key concern. Students choosing between online and on-campus programs-even within the same institution-may differ on any number of unobservable dimensions. We address these selection concerns in multiple ways (described in detail

\footnotetext{
12 Interview with Wilmer Ángel, SENA's Virtual and Distance Training Group (August 15, 2018). SENA's website corroborates this indicating that distance learning is a combination between online and in-person training while virtual learning is $100 \%$ online: https://sena.territorio.la/cms/index.php/titulada ${ }^{13}$ Disaggregating these categories yields qualitatively similar results.
} 
below) -including with a bounding exercise and an instrumental variables approach—but our first step is to draw on one final dataset from the Colombian government to better control for students' ability prior to college enrollment.

Saber 11 is a test administered to high school graduates since 2000 . The test is used as part of the college admissions process and is designed to measure high school achievement. Although some consider it to have higher stakes than the college exit exams, the test includes subject areas and competencies that are similar to college exit exams, including: math, critical reading, English, and civics, as well as social sciences and natural sciences. It also includes information on students' demographics and resources measured in the $11^{\text {th }}$ grade. We draw on many of these variables to implement our inverse probability weighting, thereby cutting our Saber TyT and Pro samples down to the subset of younger students who attended $11^{\text {th }}$ grade between 2008 and 2016 who can be matched to their high school test scores. We caution that our results may not be generalizable to older adult students. We also drop a small number of students who attended specialized teacher training high schools. After these restriction, we are left with about 120,000 students in the Saber TyT and 387,000 in the Saber Pro.

Finally, to implement our instrumental variables approach, we merge our studentlevel data with data on the rollout of high-speed Internet from the Colombian Department of Telecommunications. We obtained quarterly data on residential and commercial Internet speed and number of users in each municipality by social stratification level from 2010 to 2014. 


\section{Methods}

Non-random selection of students into online institutions and programs presents a challenge in obtaining causal estimates of the impact of online coursework on student outcomes. Students in online programs are likely to differ substantially from on-campus students on a number of observable and unobservable dimensions that may be correlated with test scores.

To begin to address this challenge, our large sample size and rich pre-college data allow us to generate an inverse-probability weighted (IPW) sample of on-campus students that more closely match the online students in our sample. ${ }^{14}$ The weight for an on-campus student $i$, is calculated as $W_{i}=\hat{P}_{O} /\left(1-\hat{P}_{O}\right)$, where $\hat{P}_{O}$ is the predicted probability of enrolling in an online program based on the following probit model: ${ }^{15}$

$$
\begin{gathered}
P_{\text {Oi }}=\gamma_{0}+\gamma_{1} \text { Female }+\gamma_{2} \text { Age }+\gamma_{3} \text { SES } 11+\gamma_{4} \text { Technical HS }+\gamma_{5} \text { Internet11 } \\
+\gamma_{6} \text { Scores11 }+\mu_{i t}
\end{gathered}
$$

$P_{O i}=1$ if the student reported participating in a distance or virtual education program. Age is measured in the year the student took the college exit exam. SES11 is each student's socioeconomic status measured in $11^{\text {th }}$ grade-prior to college enrollment. The measure ranges from 1-6 (with 1 indicating the lowest SES group and 6 the highest) and is assigned to by the Colombia government based on a student's address. We also control for ability by adding a vector of $11^{\text {th }}$ grade test scores, Scores11. We include the full set of math, reading,

\footnotetext{
14 We prefer IPW to matching to keep all observations, but as a robustness check, we also implement a coarsened exact matching technique following King (2019). Results are similar and reported in Appendix Tables A3-A6.

15 We convert to the odds scale for an estimate of the Average Treatment on the Treated (ATT). This strategy gives relatively more weight to the comparison individuals who are similar to the treated persons and less weight to those who are dissimilar from the treated persons, as described by Lee and Little (2017) and Hirano et al. (2003).
} 
writing, English, Spanish, physics, social science, biology, and philosophy scores (measured as z-scores with a mean of zero and standard deviation of one) in our model. Technical HS is an indicator for students attending a technical high school and equals zero for students attending academic high schools. Internet is an indicator for whether the student's home in $11^{\text {th }}$ grade had an internet connection. We include both variables as they may predict interest or ability to access online education.

The idea of the IPW approach is that the controls included in the probit regression are sufficient to mitigate the effect of confounding factors. The identifying assumption of the approach is that after weighting, the treatment (online) and control (on-campus) students are similar not only on observables, but also on any unobservables that may be correlated with outcomes. Since this is a strong assumption, we push further to add a comprehensive set of fixed effects to our model that allows us to assess difference for matched students within an institution-degree-major combination, as well as within each level (institution, degree, and major) separately.

To implement the fixed effects approach, we estimate the impact of online enrollment on college exit exam test scores for our weighted sample according to the following:

$$
\text { Score }_{i t d h m}=\beta_{0}+\beta_{1}\left(\text { Online }_{i}\right)+\boldsymbol{d}_{\boldsymbol{t}}+\boldsymbol{d}_{\boldsymbol{m}}+\boldsymbol{d}_{\boldsymbol{h}}+\boldsymbol{d}_{\boldsymbol{d}}+\boldsymbol{d}_{\boldsymbol{f}}+\varepsilon_{i t d h m}
$$

Where Score is a z-score for either the quantitative analysis, reading, writing, English, civics, or field exam taken at the end of college. We include fixed effects for the semester and year the exam is taken $\left(\boldsymbol{d}_{\boldsymbol{t}}\right)$, municipality $\left(\boldsymbol{d}_{\boldsymbol{m}}\right),{ }^{16}$ higher education institution

\footnotetext{
16 There are 1,101 municipalities in our data. Including these as fixed effects controls for substantial urbanrural differences in the country.
} 
$\left(\boldsymbol{d}_{\boldsymbol{h}}\right)$, degree type (either "tecnico professional" or "tecnologico" in the Saber TyT) $\left(\boldsymbol{d}_{\boldsymbol{d}}\right)$, and field of study or major $\left(\boldsymbol{d}_{\boldsymbol{f}}\right) \cdot{ }^{17}$ In some specifications we include fixed effects for the interaction of institution-degree-major, as well as two-way interactions of each indicator (e.g., degree-major). With these controls, the identifying assumptions change slightly, so that within an institution-degree-major combination (e.g., SENA, tecnológico degree in health) the online and weighted on-campus groups are similar. We run our model separately for bachelor's degree programs using the Saber Pro data, rather than the Saber TyT, and our specification changes slightly due to data availability. ${ }^{18}$ To explore heterogeneity, we run our model on sub-samples of the data including by sector (public vs. private), major, gender, and age.

To address concerns about bias from remaining unobservable characteristics, we implement three different approaches. First, we explore differences in the correlates of online and on-campus enrollment for our sample and subsamples. Next, we conduct a bounding exercise based on Oster (2017). Oster's approach extends work by Altonji et al. (2005) assessing coefficient movements as observed controls are added to the regression model. The key assumption underlying the approach is that the selection bias from observed characteristics is informative of selection on unobservables. We calculate a coefficient of proportionality, $\delta$, that represents how large the effect of unobservables must be relative to the effect of observables for the treatment effect to be zero. That is, the true effect of online programs, $\beta^{*}$, can be thought of as a function of our estimate of $\beta_{1}$ from our

\footnotetext{
${ }^{17}$ Given the large number of fields of study, we group them into seven major categories (e.g., agriculture, health, art \& design, engineering, tourism, sports \& recreation).

${ }^{18}$ Specifically, technical high school and English language exam data are not available. We also drop the degree fixed effects, since they are not relevant since all students obtain bachelor's degrees.
} 
main controlled specification (here denoted $\tilde{\beta}$ ), the estimate from an uncontrolled regression, $\dot{\beta}$, and the coefficient of proportionality $\delta$, rescaled by the movement of the Rsquared, as follows:

$$
\beta^{*} \approx \tilde{\beta}-\delta(\dot{\beta}-\tilde{\beta})\left[\frac{(\operatorname{Rmax}-\tilde{R})}{(\tilde{R}-\dot{R})}\right]
$$

Where Rmax is the maximum value for the R-squared that would result if all unobservables were included the regression. We specify a maximum R-squared following Oster's heuristic approach of $\operatorname{Rmax}=1.3 * \widetilde{R}$.

Finally, we implement an instrumental variables approach. Similar to Goolsbee et al. (2010), Deming et al. (2016), and Dettling et al. (2018), in the U.S., we draw on the timing of the rollout of high-speed Internet infrastructure in the country. In the first stage we estimate:

$$
\text { Online }_{i}=\gamma_{0}+\gamma_{1} Z_{i t}+\gamma_{2} \boldsymbol{X}_{i t}+\mu_{s i t}
$$

$\mathbf{X}$ is a vector of observable individual characteristics. The instrument, $\mathrm{Z}$, is the average Internet download speed, measured in MHz divided by 1,000 in an individual's town and SES level (as determined by the government for each neighborhood), in the year the student was in $11^{\text {th }}$ grade. We hypothesize that higher Internet speeds in a student's neighborhood around the time of college enrollment should increase the likelihood of enrolling in an online college program, but should not have an independent effect on exit exam scores several years later. In the second stage, we estimate:

$$
\text { Score }_{\text {sdict }}=\alpha_{0}+\alpha_{1}\left(\widehat{\text { Onllne }}_{c}\right)+\alpha_{2} \boldsymbol{X}_{i t}+\boldsymbol{d}_{\boldsymbol{t}}+\boldsymbol{d}_{\boldsymbol{m}}+\varepsilon_{\text {sit }}
$$

The identifying assumption of the IV approach is that, conditional on observables, Internet speed only affects college exit test scores through its effect on access to online education. 


\section{Who enrolls in online programs?}

We report our variable means for online and on-campus students in both the Saber Pro and Saber TyT samples in Table 1. There are noticeable differences in characteristics of online and on-campus bachelor's degree students in columns (1) and (2). In this sample, online students are more likely to be female, older, and have lower test scores than their on-campus peers. After weighting in column (3), the two groups are much more similar. Standardized mean differences are generally small, although both age and chemistry scores show differences above 0.2 , suggesting that some selection may remain. ${ }^{19}$ We therefore rely more heavily on our results for technical students and explore selection issues further below.

Among technical students, even before weighting, online and on-campus students look quite similar in columns (5) and (6). Online students are more likely to be female and have lower $11^{\text {th }}$ grade test scores, but they are similar on age and socioeconomic status. After weighting, the characteristics of the on-campus students in column (7) are nearly identical to those of the online students in column (5). Standardized mean differences between the online students and our IPW-matched on-campus students (reported in column 8) reveal only minor remaining differences less than 0.2 , suggesting that our main analytic sample is balanced.

Mean outcomes are reported for each sample in Table 2. In both samples, these unconditional means show lower scores for online students, relative to on-campus

\footnotetext{
${ }^{19}$ Standardized differences are frequently used to assess balance with the IPW approach. The main advantage
} of this approach is that it is not sensitive to changes in sample size (Austin 2009). 
students. We also include the rates of online program enrollment in both samples in the first row: online enrollment is much less common among bachelor's degree students at just $6.6 \%$ compared to $36 \%$ among technical students. Finally, results of our propensity score analyses used to generate the weights reflect the same patterns demonstrated in Table 1: these results are reported in Appendix Table A2.

\section{Results}

\section{Bachelor's Degree Students}

We begin by looking at the outcomes of bachelor's degree students in the Saber Pro data in Table 3 using our IPW approach. We find large, negative point estimates that are fairly consistent across specifications, suggesting that online enrollment is associated with lower test scores across all exams and models. Major appears to play a small role in our estimates, reducing coefficients only slightly in column (2), relative to the baseline model with just municipality and time fixed effects in column (1). The differences between online and on-campus students grow when adding institution fixed effects in column (3), suggesting more heterogeneity across universities offering bachelor's degrees, relative to differences across majors. On average, across all specifications, online students perform worse in math (Panel A) by about -0.11 standard deviation, with slightly larger differences for reading and writing of about -0.15 (Panels B and C).

In Table 4, we consider bachelor's degree students in the private and public sectors separately. Students in bachelor's degree programs are fairly evenly distributed across public and private institutions in our sample, with roughly 64 percent of students in the private sector and no single institution dominating the market in either sector. We show 
our fully-loaded model with institution-by-major fixed effects..$^{20}$ Results are similar in both sectors, with only slightly larger (more negative) effects for online students in public institutions. The most notable difference is for reading exams, where online students in public institutions perform much worse than their on-campus counterparts $(-0.165$ standard deviations), while the difference is less pronounced in the private institutions (0.072 standard deviations). Overall, our results suggest that among bachelor's degree programs, online students perform significantly worse on college exit exams than students in traditional on-campus programs.

\section{Vocational and Technical Programs}

We next turn to students who complete either three-year tecnologico or two-year tecnico professional degrees and are represented in the Saber TyT data. In Table 5, we present the results of our IPW models for the quantitative college exit exam. Panel A reports the results for all institutions.

In column (1)—including only municipality and year fixed effects—we find that (unlike for bachelor's degrees) online technical programs are not associated with significantly or meaningfully lower test scores than on-campus programs. Controlling for degree (three-year vs. two-year) makes little difference in column (2). ${ }^{21}$ When we add major field of study in column (3), we observe a negative and significant point estimate of 0.04. We consider this specification more reliable than that in column (1) as it accounts for

\footnotetext{
${ }^{20}$ Results for other models (just major fixed effects and just institution fixed effects) are similar.

${ }^{21}$ Robustness checks using sub-samples of two-year and three-year degrees yielded similar results.
} 
potential differences in the distribution of fields across online and on-campus programs. Comparing the coefficients suggests some heterogeneity by major.

Of course, even within the same field or degree, online programs and courses offered by different institutions may vary substantially in quality. Comparing students in the same institutions in column (4) changes our estimates substantially. Controlling for institution fixed effects (and then interacting those with degree and major fixed effects in cols. (5)-(7)) reveals surprising positive and significant test score gains to online enrollment between 0.09 to 0.12 standard deviation higher test scores for online students.

To better understand these fluctuating results, we take a closer look at SENA-the main public technical institution in the country. We consider it separately in Panels B and C. In Panel B, we drop SENA and limit the sample to private institutions in the country. ${ }^{22}$ The results are dramatically different: online students perform worse on exit exams in every specification. Results are significant and suggest effects between -0.03 and -0.07 standard deviations in columns (3)-(6).

In contrast, Panel C presents the first results we are aware of for SENA. Within SENA, students who take online classes see exit test scores that are about 0.17 standard deviations higher that students taking only on-campus courses. This result holds and is remarkably consistent in magnitude, even when we consider differences only within the same degree and major in column (4).

\footnotetext{
${ }^{22}$ As noted earlier, there is only one other small public institution offering online technical degrees in Colombia. Because it charges tuition, we include it with private institutions. When we instead combine it with SENA results are unchanged. See Appendix Table A7. For simplicity, we refer to the group of mostly private institutions as "private" throughout.
} 
Tables 6 and 7 show results for reading and writing exam scores, respectively. Similar to the quantitative exam, in the full sample and in private institutions, online technical students appear to perform worse on exams, while in SENA, online students again do better in both reading and writing. These countervailing effects are evident in the full sample, as estimates (again) change considerably when introducing institution-specific fixed effects. We find similar patterns for English, civics, and the largest technical field exam - health promotion—as shown in Appendix Tables A8, A9, and A10, respectively.

\section{Heterogeneity}

We next explore whether students' math, reading, and writing scores differ by field of study, as it is possible that more computer-oriented fields (e.g., information technology) might lend themselves better to online study than more human-orientated fields (e.g., health). Results for sub-samples of the four fields with the most graduates are reported in Table $8{ }^{23}$ Interestingly, the human-centered fields of health and tourism reveal smaller differences in the performance of online students, while engineering shows particularly stark differences.

We ask whether effects differ by age and gender in Table 9. In Panel A, males appear to do worse than females-experiencing slightly more negative effects of online learning in private institutions and smaller positive effects in SENA. We see no discernable pattern by age category in Panel B, in part due to small sample sizes in some groups.

\section{Selection}

${ }^{23}$ We do not break SENA out separately in the field of study analysis, as sample sizes get quite small. 
Although we can control for many background characteristics with our IPW approach and fixed effects, it is still possible that the differences we observe are driven by differential selection or attrition. As for attrition, we are encouraged that SENA reports only slightly higher dropout rates than other institutions, as noted previously. It is more likely that our estimates reflect positive selection within SENA and negative selection within private institutions-all on dimensions that are not observable. We address this concern in several ways.

First, we examine the correlates of online enrollment in private institutions and SENA using the probit model in equation (1). We report these results in columns (2) and (3) of Appendix Table A2. We see only a few differences in sign or significance generally. Older students are less likely to enroll online in SENA but more likely to enroll online in private institutions. In a difference that might hint at positive selection, students who attended technical high schools are more likely to enroll online in SENA, while the effect is close to zero for private institutions. Eleventh grade test scores reveal only small differences, with private online students having lower scores on Spanish, English, and biology, while SENA students are more likely to go online with higher scores on chemistry, but there are no other significant predictors of online enrollment among the other seven subject tests. Any positive selection into SENA's online programs is not clear based on these observable dimensions.

To further explore the potential role of unobserved heterogeneity, we conduct a bounding exercise following Oster (2017) in Table 10. Specifically, we calculate the coefficient of proportionality, $\delta$, according to equation (3) in column (3). In Panel A, the $\delta$ for quantitative exams suggests that any remaining unobservables would have to be more 
than 33 times as large as the observables for the treatment effect to be zero. Moreover, unobserved selection would have to go in the opposite direction of the observed selection, as indicated by the negative sign. For reading exams, selection on unobservables would have to be three times as large as the selection on observables to eliminate our treatment effect. Both suggest that our results for these outcomes are likely to be robust to unobservables. The writing results, however, are less robust, with $\delta$ less than 1. In Panel B, for private institutions, the pattern is reversed with writing seemingly more robust, but much lower values of $\delta$ generally, suggesting that selection on unobservables may be more problematic for this subsample. For SENA, our results are quite strong with all $\delta$ 's larger than one in absolute value, suggesting little selection on unobservables under the assumptions of the Oster approach.

We next implement the instrumental variables approach described above in equations (4) and (5). We report our results in Table 11. The first stage is significant, but goes in the opposite of the expected direction, showing higher Internet speeds correlated with a lower likelihood of enrolling online. The unexpected direction of the effect signals the potential failure of the exclusion restriction, as Internet speed may be correlated with other factors determining online or on-campus enrollment. We are somewhat encouraged that effect sizes in the second stage reveal the same pattern as in our IPW models-negative effects generally, but positive (although implausibly large and not statistically significant) for SENA. Given the potential failure of the identifying assumption of this approach, we prefer our IPW models. 


\section{Discussion}

What drives the striking differences in outcomes for online students in SENA, relative to other degrees and institutions? We conducted interviews with SENA administrators in the Virtual and Distance Training Group to shed light on our results. A few points stood out.

The quality of instruction may be higher for online than on-campus courses in SENA. Online programs and classes benefit from the best instructors in SENA, as instructors can teach virtually from main campus. In contrast, in-person instruction at branch campuses in rural areas may vary in quality, drawing on local instructors that may or may not be as qualified or experienced as those leading online classes.

SENA is known for its synchronous, yet flexible online coursework. Students in online classes engage directly with instructors in live virtual instruction for about 2 hours per week, which might be one key to the success of these programs. However, administrators also note that students who have trouble with internet connectivity or face other challenges can also access recorded lectures to learn asynchronously, if needed.

SENA's pedagogical approach is also unique, using hands-on "Formative Projects" to enhance student learning. For example, for a business certificate, students might be assigned to conduct the annual accounting audit for a real company. During the course of the semester, students learn how to read the company's balance sheet, work with spreadsheets, and do simple calculations.

While these approaches are promising and our bounds test is suggestive that selection on unobservables is not the main driver behind SENA's positive outcomes, we cannot rule out selection completely. It could be that SENA's admissions quizzes accurately predict who 
will have the cognitive skills or motivation to succeed. Even with these screening mechanisms, however, only about 40 percent of online students complete the degree requirements, so it seems unlikely that the admissions quizzes could drive the positive outcomes we observe.

One administrator suggested to us that online students may be more motivated than inperson students. Online learning requires more independent learning, so online students need to put in more effort to stay organized and teach themselves the material if they fall behind. It is possible that SENA's positive outcomes are driven by highly-motivated students who are able to complete online degrees. However, what is less clear is how or why SENA would differentially attract these students into online programs while their private sector competitors would not.

\section{Conclusion}

We believe that this study is among the first to assess the impact of online college programs on student test scores. We examine student scores on mandatory college exit exams, comparing outcomes of a matched sample of online and on-campus students in the same institutions, degrees, and majors.

We find that test scores are lower for online students than for on-campus students in bachelor's degree programs. On average, online bachelor's degree students score about 0.11 standard deviations lower in math and 0.15 lower for math and reading than students in more traditional campus-based programs. In general, our results support the findings in the U.S. literature of worse learning outcomes for online students relative to those taking classes on campus. 
At the sub-baccalaureate level, for technical degree students in short-term programs, our findings suggest that institutional factors contribute to differences in student outcomes between online and on-campus programs. For most private institutions, online students perform worse on college exit exams-across all three major subject areas (math, reading, and writing). Math, reading, and writing scores average about -0.05 of a standard deviation lower for online technical students in private institutions, relative to their on-campus peers.

However, online students in the nation's largest public vocational college, SENA, fare better than their on-campus counterparts, for reasons that are not entirely clear. Our weighting strategy allows us to control for critical background characteristics including socioeconomic status and 11 grade test scores, and our fixed effects can control for differences across institutions, degrees, and majors. Our bounding exercise further suggests that selection on unobservables is not driving our estimates. Yet, we cannot rule out that online students—and particularly the online graduates that we study here-may be positively selected in SENA with more motivated students completing online degrees.

On the other hand, interviews with SENA staff suggest that several features of their online programs may make them more successful than other forms on online education. It is possible that SENA is getting online learning right, while the private institutions in the country-many of them connected to international for-profit chains-have online programs that are less successful at improving student learning.

Policymakers in Colombia and other countries with rapidly expanding postsecondary enrollment should pay close attention to the growing number of private 
institutions and online programs to ensure that all students receive a high-quality

education. Differences in outcomes by sector and mode should be considered in the design of financial aid programs for low-income students, such as Colombia's new Generación E program. Assuring the quality of online programs is all the more important as the global COVID-19 pandemic has pushed more student online worldwide.

Much more research is needed to fully understand the learning outcomes of online students. We encourage future researchers to push further in gathering, accessing, and exploring new data sources-such as student transcripts or tax records-to address questions around course-taking, persistence, degree completion, earnings gains, and employment of online students. This study is just a first step in understanding the learning outcomes of online students in Colombia-and we find reason to be wary. Further analyses are needed to understand the promises and perils of virtual learning and to ensure the success of millions of college students in Latin America and around the world who have been pushed online during the pandemic.

\section{References}

Alpert, W. T., K. A. Couch, and O. R. Harmon (2016). A randomized assessment of online learning. American Economic Review, 106(5), 378-82

Altonji, J., Conley, T., Elder, T., and Taber, C. (2005). Selection on Observed and Unobserved Variables: Assessing the Effectiveness of Catholic Schools. Journal of Political Economy, 113(1): 151-184.

Austin, P. C. (2009). Balance diagnostics for comparing the distribution of baseline covariates between treatment groups in propensity-score matched samples. Statistics in Medicine, 28(25), 3083-3107.

Bettinger, E. P., L. Fox, S. Loeb, and E. S. Taylor (2017). Virtual classrooms: How online college courses affect student success. American Economic Review 107(9), 2855-75.

Boada, A., \& Cardona, G. (2017). Análisis comparativo del desempeño de estudiantes de las modalidades, presencial y virtual en las pruebas saber pro-Competencias Generales-. Caso de 
la IES Ceipa.

https://www.researchgate.net/profile/Antonio Boada/publication/317624630

Bowen, W. G., M. M. Chingos, K. A. Lack, and T. I. Nygren (2014). Interactive learning online at public universities: Evidence from a six-campus randomized trial. Journal of Policy Analysis and Management, 33(1), 94-111.

Burke, L. (2020, October 27). Moving Into the Long Term, Inside Higher Ed,. https://www.insidehighered.com/digital-learning/article/2020/10/27/long-term-onlinelearning-pandemic-may-impact-students-well

Cadena-Cruz, T. P. (2017). Con ojos de tutora: Una mirada a los programas virtuales desarrollados por el SENA. Rutas de formación: Prácticas y Experiencias, 4, 55-59.

Camacho, Adriana and Messina, Julian and Uribe Barrera, Juan. (February 14, 2017). The Expansion of Higher Education in Colombia: Bad Students or Bad Programs? Documento CEDE No. 2017-13. http://dx.doi.org/10.2139/ssrn.2921965

Carranza, J.E. and M.M. Ferreyra 2019. Increasing Higher Education Access: Supply, Sorting, and Outcomes in Colombia, Journal of Human Capital, 13(1), 95-136.

Cayon, E., Correa, J. S., \& Sarmiento-Sabogal, J. (2017). Does Attending a Public or Private University Make a Difference for Students in Colombia?. International Review of Management and Marketing, 7(2), 293-299.

Cellini, S. (2020). The Alarming Rise in For-Profit College Enrollment. The Brookings Institution. https://www.brookings.edu/blog/brown-center-chalkboard/2020/11/02/thealarming-rise-in-for-profit-college-enrollment/

Deming, David. J., Claudia Goldin, and Lawrence F. Katz (2012). The For-Profit Postsecondary School Sector: Nimble Critters or Agile Predators? Journal of Economic Perspectives 26(1): 139-164.

Deming David J., Lovenheim M., Patterson RW. (2016). The Competitive Effects of Online Education. NBER Working Paper 22749.

Dettling, Lisa J., Sarena F. Goodman, and Jonathan Smith (2018). Every Little Bit Counts: The Impact of High-speed Internet on the Transition to College, Finance and Economics, Review of Economics and Statistics, 100(2): 260-273.

Domingue, B. W., Lang, D., Cuevas, M., Castellanos, M., Lopera, C., Mariño, J. P., Molina A. \& Shavelson, R. J. (2017). Measuring student learning in technical programs: A case study from Colombia. AERA Open, 3(1), 1-11.

El Observatorio de la Universidad Colombiana (2020, Dec. 15). Valores de matrículas de programas profesionales en instituciones privadas.

https://www.universidad.edu.co/valores-de-matrlas-de-programas-profesionales-eninstituciones-privadas/ 
Ferreyra, M.M., J.B. Alvarez, C. Avitabile, F. Haimovich, and S. Urzua (2017). At a Crossroads: Higher Education in Latin America and the Caribbean. Directions in Development. Washington, DC: World Bank.

Figlio, D., M. Rush, and L. Yin (2013). Is it live or is it internet? Experimental estimates of the effects of online instruction on student learning. Journal of Labor Economics 31(4), 763784.

Gil, F., Rodríguez, V., Sepúlveda, L., Rondón, M. \& Gómez-Restrepo, C. (2013). Impacto de las facultades de medicina y de los estudiantes sobre los resultados en la prueba nacional de calidad de la educación superior (SABER PRO). Revista Colombiana de Anestesiología. 41(3):196-204

Gomez, N. (2015). Three essays on human capital and labor markets for college graduates in Colombia. Ph.D. Thesis, Ohio State University. https://search.proquest.com/openview/d1762386c48293af7d981d020d199fdf/1?pqorigsite $=$ gscholar $\& \mathrm{cbl}=18750 \&$ diss $=\mathrm{y}$

Goodman, J., Melkers, J., and Pallais, A. (2019). Can Online Delivery Increase Access to Education? Journal of Labor Economics, 37(1): 1-34.

Goolsbee, A., Lovenheim, M.F., and Slemrod, J. (2010). Playing With Fire: Cigarettes, Taxes and Competition from the Internet. American Economic Journal: Economic Policy 2(1): 131154.

Guarín, A., Londoño, S., Medina, C., Parra, J., Posso, C., \& Vélez, C. E. (2016). Estimating the Effect of Attending a Public versus a Private University in Colombia on Academic Achievement. Banco de la Republica de Colombia [Bank of the Republic of Colombia] Working Paper No. 968.

Hart, C.M.D., Friedmann, E. \& Hill, M. (2018). Online course-taking and student outcomes in California Community Colleges. Education Finance and Policy 13(1): 42-71.

Hess, Abigail (2020, March 26). How Coronavirus Dramatically Changed College for Over 14 million students, CNBC.com. https://www.cnbc.com/2020/03/26/how-coronaviruschanged-college-for-over-14-million-students.html.

Hirano, Keisuke, Guido Imbens, and Geert Ridder (2003). Efficient Estimation of Average Treatment Effects Using the Estimated Propensity Score, Econometrica, 71(4): 1161-1189.

Hoxby, C. (2015) Online Postsecondary Education and Labor Productivity in Education, Skills, and Technical Change: Implications for Future U.S. GDP Growth, Hulten and Ramey.

Joyce, T., S. Crockett, D. A. Jaeger, O. Altindag, and S. D. O'Connell (2015). Does classroom time matter? Economics of Education Review 46, 64-77.

Krieg, J. M. and S. E. Henson (2016). The educational impact of online learning: How do university students perform in subsequent courses? Education Finance and Policy, 11(4), 426-448. 
Lederman, D. (2020, July 29). Virtual Learning Will be Better this Fall, Right?. Inside Higher Ed. https://www.insidehighered.com/digital-learning/article/2020/07/29/will-virtuallearning-be-better-fall-will-it-be-better-enough.

Lee, Jaehoon and Todd D. Little (2017). A Practical Guide to Propensity Score Analysis for Applied Clinic Research, Behaviour Research and Therapy, 98: 76-90.

López, C. (2014, February). Las Universidades no son instituciones con ánimo de lucroLas Universidades no son instituciones con ánimo de lucro [Blog post]. https://www.claudialopez.com/las-universidades-no-son-instituciones-con-animo-de-lucro/

López, A. \& Janssen, G. (2010). Validation Study of Colombia's ECAES English Exam. Lenguaje, Universidad de los Andes, 38 (2)., 423-448.

National Student Clearinghouse (2020). Enrollment Picture Worsens as More Schools Report to National Student Clearinghouse. September 24. https://public.tableau.com/profile/researchcenter\#!/vizhome/FallFlashReport2October/ Fall2020EnrollmentNo_2

OECD, International Bank for Reconstruction and Development, The World Bank (2012). Reviews of National Policies for Education: Tertiary Education in Colombia 2012, OECD Publishing. http://dx.doi.org/ 10.1787/9789264180697-en

Ortiz, D., Gómez, E., \& Arias, N. (2015). Resultados en Saber Pro de estudiantes de modalidad presencial y virtual en dos universidades colombianas. Revista Digital: Academia y Virtualidad, 8(2), 100-111.

Oster, E. (2017). “Unobservable Selection and Coefficient Stability," Journal of Business and Economic Statistics, 37(2), 187-204.

Riehl, E., Saavedra, J., and Urquiola, M., "Learning and Earning: An Approximation to College Value Added in Two Dimensions, " chapter in forthcoming book, C. Hoxby and K. Stange, eds., Productivity in Higher Education, University of Chicago

Press. https://www.nber.org/chapters/c13877.pdf

Paez, P., \& Teelken, C. (2016). Perceived quality of private education and fears of stratification: Investigating the propositions of human capital theory by exploring the case of Colombia. Policy Futures in Education, 14(6), 597-616.

Rodríguez Albor, G., Gómez Lorduy, V., \& Ariza Dau, M. (2014). Calidad de la educación superior a distancia y virtual: Un análisis de desempeño académico en Colombia. Investigación \& Desarrollo, 22(1).

Salazar-Ramos, R., and Melo-Cortés (2013). Lineamientos conceptuales de la modalidad de educación a distancia. In Arboleda-Toro \& Rama-Vitale, La educación superior a distancia y virtutal en Colombia: Nuevas realidades, ACESAD, 81-111.

Sarmiento, J. \& Sandoval, L. (2008). Análisis descriptivos de los resultados de los ECAES en economía (2004-2006) [Descriptive analysis of the ECAES results in economics (20042006)]. Revista de la Facultad de Ciencias Sociales, Universidad Militar Nueva Granada. 
Semana (2018, October 24). Universidades con ánimo de lucro en Colombia ¿riesgo u oportunidad? Retrived from:https://www.semana.com/educacion/articulo/universidadescon-animo-de-lucro-en-colombia-una-discusion-vieja-que-reaparece-en-elcongreso/588042

SENA (2020, October 13). Quiénes Somos. https://www.sena.edu.co/esco/sena/Paginas/quienesSomos.aspx

Velasquez-Gaviria, D. (2020). Public vs Private University: Evidence from Colombian National Test Scores. Working Paper, Maastricht University, School of Business and Economics.

$\mathrm{Xu}, \mathrm{D}$. and S. S. Jaggars (2014). Performance gaps between online and face-to-face courses: Differences across types of students and academic subject areas. The Journal of Higher Education 85(5), 633-659. 
Table 1. Summary Statistics and Balance

\begin{tabular}{|c|c|c|c|c|c|c|c|c|}
\hline \multirow[b]{3}{*}{ Variable means (st. dev) } & \multicolumn{4}{|c|}{ Saber Pro - Bachelor's Degree Programs } & \multicolumn{4}{|c|}{ Saber TyT - Technical Programs } \\
\hline & Online & $\begin{array}{c}\text { On- } \\
\text { campus }\end{array}$ & $\begin{array}{c}\text { On- } \\
\text { campus } \\
\text { (IPW) }\end{array}$ & $\begin{array}{c}\text { Standardized } \\
\text { Difference } \dagger \\
\operatorname{col}(1)-\operatorname{col}(3)\end{array}$ & Online & $\begin{array}{c}\text { On- } \\
\text { campus }\end{array}$ & $\begin{array}{c}\text { On- } \\
\text { campus } \\
\text { (IPW) }\end{array}$ & $\begin{array}{c}\text { Standardized } \\
\text { Difference } \dagger \\
\operatorname{col}(1)-\operatorname{col}(3)\end{array}$ \\
\hline & $(1)$ & $(2)$ & (3) & $(4)$ & (5) & $(6)$ & $(7)$ & $(8)$ \\
\hline Female & $\begin{array}{c}0.73 \\
(0.44)\end{array}$ & $\begin{array}{c}0.58 \\
(0.49)\end{array}$ & $\begin{array}{c}0.70 \\
(0.46)\end{array}$ & 0.07 & $\begin{array}{c}0.59 \\
(0.49)\end{array}$ & $\begin{array}{c}0.48 \\
(0.50)\end{array}$ & $\begin{array}{c}0.58 \\
(0.49)\end{array}$ & 0.01 \\
\hline Age & $\begin{array}{l}24.00 \\
(4.83)\end{array}$ & $\begin{array}{l}22.32 \\
(1.84)\end{array}$ & $\begin{array}{l}25.88 \\
(9.70)\end{array}$ & -0.25 & $\begin{array}{l}22.49 \\
(3.52)\end{array}$ & $\begin{array}{l}22.41 \\
(2.75)\end{array}$ & $\begin{array}{l}22.52 \\
(3.33)\end{array}$ & -0.01 \\
\hline Social Stratification - 11th grade & $\begin{array}{c}1.74 \\
(0.78)\end{array}$ & $\begin{array}{c}2.76 \\
(1.23)\end{array}$ & $\begin{array}{c}1.76 \\
(0.81)\end{array}$ & -0.03 & $\begin{array}{c}1.72 \\
(0.76)\end{array}$ & $\begin{array}{c}2.01 \\
(0.85)\end{array}$ & $\begin{array}{c}1.73 \\
(0.75)\end{array}$ & 0.00 \\
\hline Home Internet - 11th grade & $\begin{array}{c}0.25 \\
(0.43)\end{array}$ & $\begin{array}{c}0.61 \\
(0.49)\end{array}$ & $\begin{array}{c}0.23 \\
(0.42)\end{array}$ & 0.05 & $\begin{array}{c}0.58 \\
(0.49)\end{array}$ & $\begin{array}{c}0.74 \\
(0.44)\end{array}$ & $\begin{array}{c}0.67 \\
(0.47)\end{array}$ & -0.19 \\
\hline Technical High School & & & & & $\begin{array}{c}0.34 \\
(0.47)\end{array}$ & $\begin{array}{c}0.31 \\
(0.46)\end{array}$ & $\begin{array}{c}0.33 \\
(0.47)\end{array}$ & 0.00 \\
\hline Math Score - Saber11 & $\begin{array}{c}-0.03 \\
(0.89)\end{array}$ & $\begin{array}{c}0.78 \\
(1.07)\end{array}$ & $\begin{array}{l}-0.15 \\
(0.99)\end{array}$ & 0.12 & $\begin{array}{c}-0.06 \\
(0.86)\end{array}$ & $\begin{array}{c}0.11 \\
(0.89)\end{array}$ & $\begin{array}{l}-0.06 \\
(0.86)\end{array}$ & 0.00 \\
\hline Spanish Score - Saber11 & $\begin{array}{c}0.04 \\
(0.92)\end{array}$ & $\begin{array}{c}0.74 \\
(0.96)\end{array}$ & $\begin{array}{l}-0.06 \\
(1.01)\end{array}$ & 0.10 & $\begin{array}{c}-0.02 \\
(0.87)\end{array}$ & $\begin{array}{c}0.12 \\
(0.88)\end{array}$ & $\begin{array}{l}-0.02 \\
(0.87)\end{array}$ & 0.00 \\
\hline Social Science Score - Saber11 & $\begin{array}{c}0.05 \\
(0.90)\end{array}$ & $\begin{array}{c}0.79 \\
(0.97)\end{array}$ & $\begin{array}{l}-0.05 \\
(1.02)\end{array}$ & 0.10 & $\begin{array}{c}-0.02 \\
(0.86)\end{array}$ & $\begin{array}{c}0.12 \\
(0.88)\end{array}$ & $\begin{array}{c}-0.02 \\
(0.86)\end{array}$ & 0.00 \\
\hline Philosophy Score - Saber11 & $\begin{array}{c}0.07 \\
(0.94)\end{array}$ & $\begin{array}{c}0.61 \\
(0.96)\end{array}$ & $\begin{array}{l}-0.08 \\
(1.26)\end{array}$ & 0.14 & $\begin{array}{c}-0.01 \\
(0.91)\end{array}$ & $\begin{array}{c}0.09 \\
(0.92)\end{array}$ & $\begin{array}{l}-0.01 \\
(0.91)\end{array}$ & 0.00 \\
\hline Biology Score - Saber11 & $\begin{array}{c}0.01 \\
(0.90)\end{array}$ & $\begin{array}{c}0.72 \\
(1.01)\end{array}$ & $\begin{array}{l}-0.12 \\
(1.04)\end{array}$ & 0.13 & $\begin{array}{c}-0.03 \\
(0.88)\end{array}$ & $\begin{array}{c}0.12 \\
(0.89)\end{array}$ & $\begin{array}{l}-0.03 \\
(0.87)\end{array}$ & 0.00 \\
\hline Chemistry Score - Saber11 & $\begin{array}{c}0.04 \\
(0.89)\end{array}$ & $\begin{array}{c}0.78 \\
(1.07)\end{array}$ & $\begin{array}{c}-0.22 \\
(1.51)\end{array}$ & 0.21 & $\begin{array}{c}-0.01 \\
(0.85)\end{array}$ & $\begin{array}{c}0.12 \\
(0.89)\end{array}$ & $\begin{array}{l}-0.01 \\
(0.86)\end{array}$ & 0.00 \\
\hline Physics Score - Saber11 & $\begin{array}{c}-0.03 \\
(0.94)\end{array}$ & $\begin{array}{c}0.53 \\
(1.02)\end{array}$ & $\begin{array}{c}-0.23 \\
(1.34)\end{array}$ & 0.17 & $\begin{array}{c}-0.02 \\
(0.91)\end{array}$ & $\begin{array}{c}0.10 \\
(0.93)\end{array}$ & $\begin{array}{l}-0.02 \\
(0.92)\end{array}$ & 0.00 \\
\hline English Score - Saber11 & & & & & $\begin{array}{c}-0.21 \\
(0.87)\end{array}$ & $\begin{array}{l}-0.03 \\
(0.94)\end{array}$ & $\begin{array}{l}-0.21 \\
(0.83)\end{array}$ & 0.00 \\
\hline Observations & 25,646 & 363,214 & 361,658 & & 43,203 & 76,832 & 76,832 & \\
\hline
\end{tabular}


Table 2. Means of Outcome Variables, On-campus and Online Students

\begin{tabular}{|c|c|c|c|c|}
\hline \multirow[b]{3}{*}{ Exam Section } & \multicolumn{2}{|c|}{ Saber Pro - Bachelor's } & \multicolumn{2}{|c|}{ Saber TyT - Technical } \\
\hline & On-Campus & Online & On-Campus & Online \\
\hline & $(1)$ & $(2)$ & (3) & $(4)$ \\
\hline$\%$ of Sample & $93.40 \%$ & $6.60 \%$ & $64.01 \%$ & $35.99 \%$ \\
\hline \multirow[t]{3}{*}{ Quantitative } & 0.38 & -0.43 & 0.09 & -0.06 \\
\hline & $(1.05)$ & $(0.83)$ & $(1.05)$ & $(0.95)$ \\
\hline & {$[363,223]$} & {$[25,652]$} & {$[76,827]$} & {$[43,194]$} \\
\hline \multirow[t]{3}{*}{ Reading } & 0.39 & -0.44 & 0.05 & -0.12 \\
\hline & $(0.99)$ & $(0.89)$ & $(1.05)$ & $(0.98)$ \\
\hline & {$[363,223]$} & {$[25,651]$} & {$[76,827]$} & {$[43,194]$} \\
\hline \multirow[t]{3}{*}{ Writing } & 0.21 & -0.27 & 0.06 & -0.10 \\
\hline & $(1.02)$ & $(0.97)$ & $(1.00)$ & $(0.96)$ \\
\hline & {$[363,065]$} & {$[25,183]$} & {$[74,719]$} & {$[42,250]$} \\
\hline
\end{tabular}

Note: Std. Dev. in parentheses and number of observations in brackets. Percent of sample is based on quantitative exam observations. 
Table 3. Effects of Online Programs on Test Scores, Bachelor's Degree Programs, SaberPro

Exam Z-Score

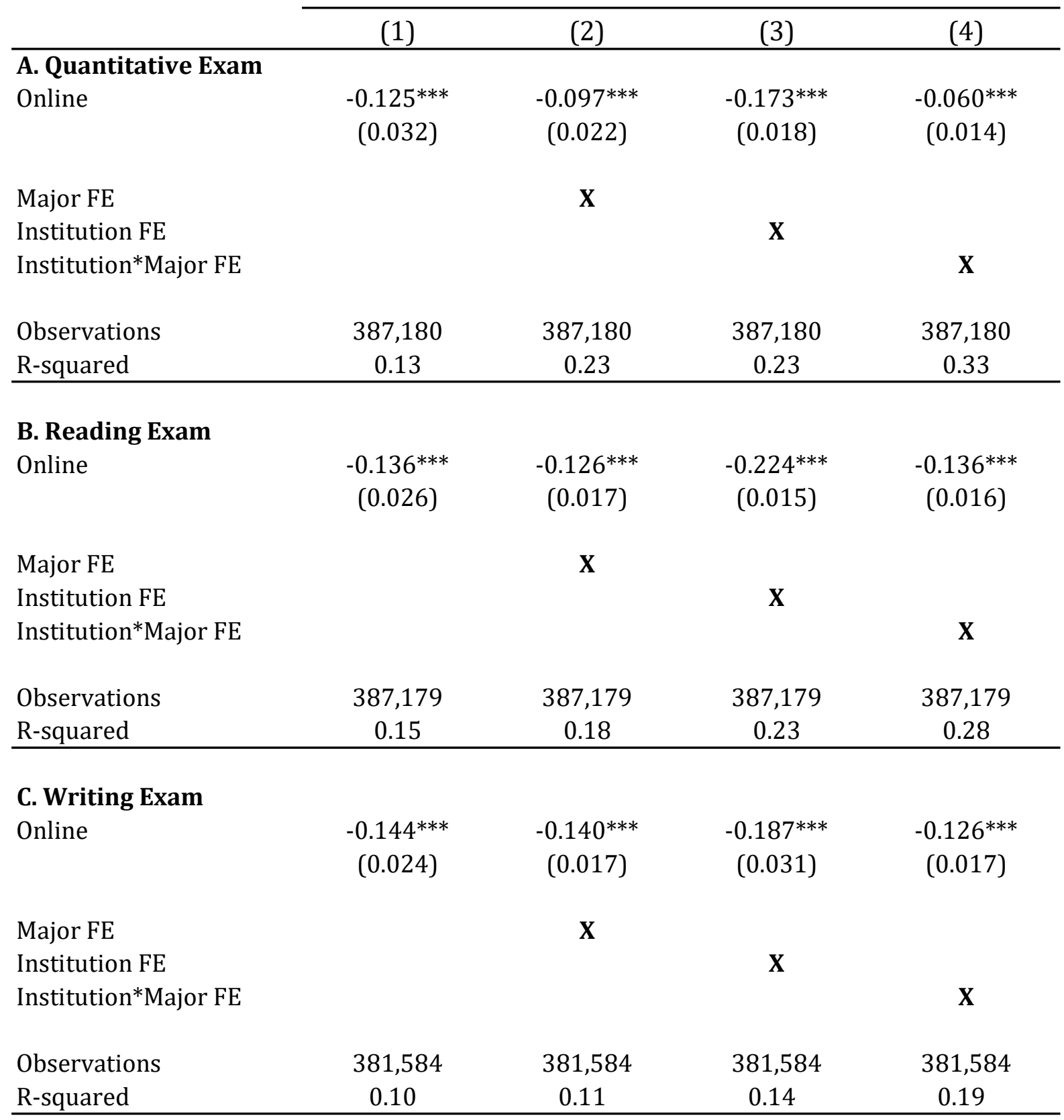

Notes: Standard errors in parentheses. ${ }^{* * *} \mathrm{p}<0.01,{ }^{* *} \mathrm{p}<0.05,{ }^{*} \mathrm{p}<0.1$. Models estimated according to equation (2). All models include year and municipality fixed effects. 
Table 4. Effects of Online Programs on Test Scores, by Sector, Bachelor's Degree Programs, SaberPro

\begin{tabular}{|c|c|c|c|}
\hline & \multicolumn{3}{|c|}{ Exam Z-Score by Sector } \\
\hline & All & Private & Public \\
\hline & (1) & (2) & (3) \\
\hline \multicolumn{4}{|l|}{ A. Quantitative Exam } \\
\hline \multirow[t]{2}{*}{ Online } & $-0.060^{* * *}$ & $-0.057^{* *}$ & $-0.064^{* * *}$ \\
\hline & $(0.014)$ & $(0.023)$ & $(0.018)$ \\
\hline Institution*Major FE & $\mathbf{X}$ & $\mathbf{X}$ & $\mathbf{X}$ \\
\hline Observations & 387,180 & 247,788 & 139,392 \\
\hline R-squared & 0.33 & 0.39 & 0.29 \\
\hline \multicolumn{4}{|l|}{ B. Reading Exam } \\
\hline \multirow{2}{*}{ Online } & $-0.136^{* * *}$ & $-0.072^{* * *}$ & $-0.166^{* * *}$ \\
\hline & $(0.016)$ & $(0.026)$ & $(0.020)$ \\
\hline Institution*Major FE & $\mathbf{X}$ & $\mathbf{X}$ & $\mathbf{X}$ \\
\hline Observations & 387,179 & 247,788 & 139,391 \\
\hline R-squared & 0.28 & 0.34 & 0.24 \\
\hline \multicolumn{4}{|l|}{ C. Writing Exam } \\
\hline \multirow[t]{2}{*}{ Online } & $-0.126^{* * *}$ & $-0.122^{* * *}$ & $-0.123^{* * *}$ \\
\hline & $(0.017)$ & $(0.029)$ & $(0.022)$ \\
\hline Institution*Major FE & $\mathbf{X}$ & $\mathbf{X}$ & $\mathbf{X}$ \\
\hline Observations & 381,584 & 244,258 & 137,326 \\
\hline R-squared & 0.19 & 0.25 & 0.15 \\
\hline
\end{tabular}

Notes: Standard errors in parentheses. ${ }^{* * *} \mathrm{p}<0.01,{ }^{* *} \mathrm{p}<0.05,{ }^{*} \mathrm{p}<0.1$. Models estimated according to equation (2). All models include year and municipality fixed effects. 
Table 5. Effects of Online Programs on Quantitative Test Scores, Technical Programs, Saber TyT

Quantitative Exam Z-Score

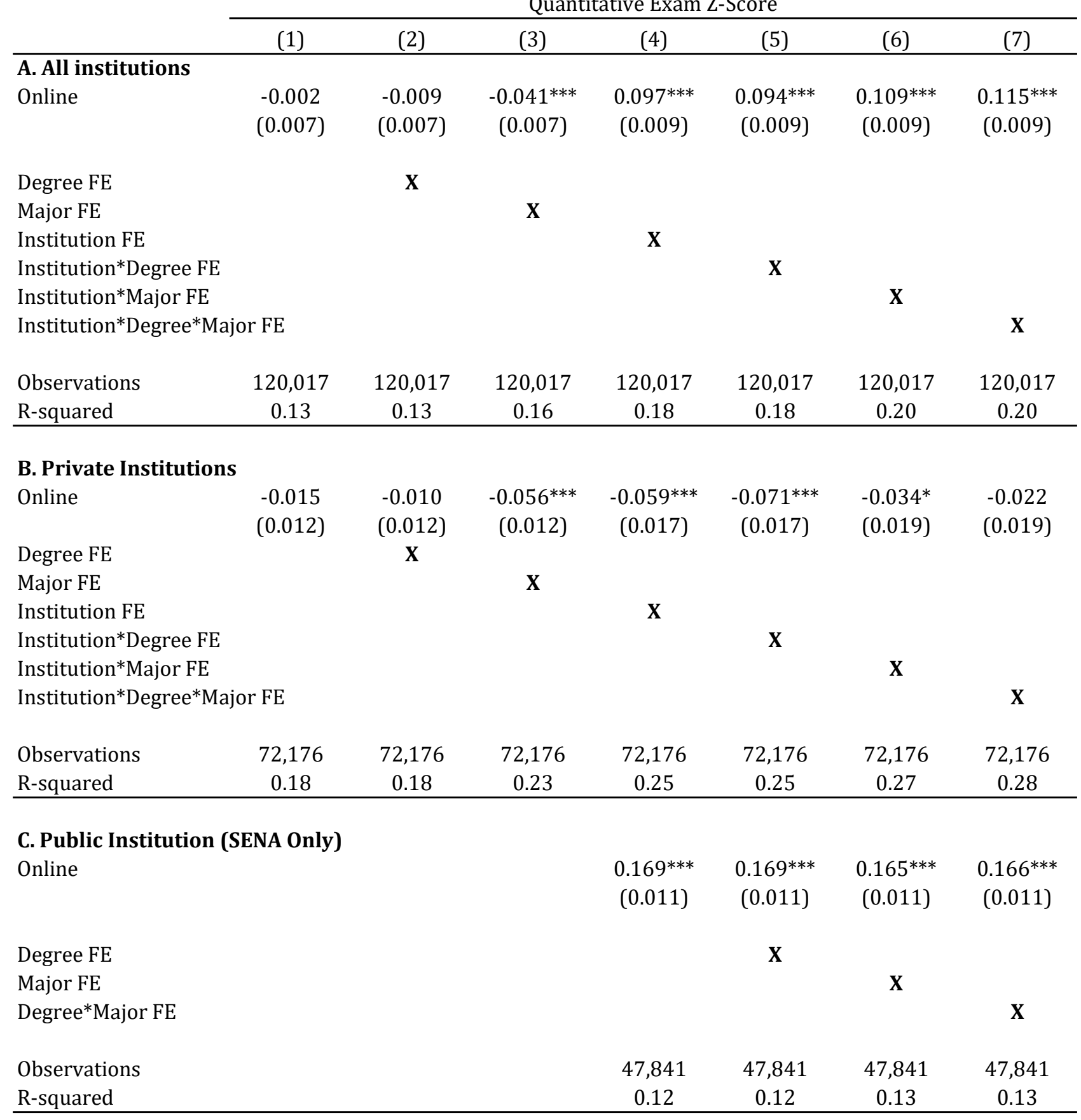

Notes: Standard errors in parentheses. ${ }^{* * *} \mathrm{p}<0.01,{ }^{* *} \mathrm{p}<0.05, * \mathrm{p}<0.1$. Models estimated according to equation (2), including semester and municipality fixed effects. Degree fixed effects are included for three-year "tecnológico" degrees and two-year "técnico profesional" degrees. 
Table 6. Effects of Online Programs on Reading Test Scores, Technical Programs, Saber TyT

Reading Exam Z-Score

\begin{tabular}{|c|c|c|c|c|c|c|c|c|}
\hline \multicolumn{3}{|c|}{ Full Sample } & \multicolumn{3}{|c|}{ Private Institutions } & \multicolumn{3}{|c|}{ Public Institution (SENA) } \\
\hline$(1)$ & $(2)$ & $(3)$ & $(4)$ & $(5)$ & $(6)$ & $(7)$ & $(8)$ & $(9)$ \\
\hline $\begin{array}{c}-0.018^{* *} \\
(0.007)\end{array}$ & $\begin{array}{c}-0.039 * * * \\
(0.007)\end{array}$ & $\begin{array}{c}0.083^{* * *} \\
(0.010)\end{array}$ & $\begin{array}{c}0.002 \\
(0.012)\end{array}$ & $\begin{array}{c}-0.046^{* * *} \\
(0.013)\end{array}$ & $\begin{array}{l}-0.027 \\
(0.021)\end{array}$ & $\begin{array}{c}0.128^{* * *} \\
(0.011)\end{array}$ & $\begin{array}{c}0.126^{* * *} \\
(0.011)\end{array}$ & $\begin{array}{c}0.127^{* * *} \\
(0.011)\end{array}$ \\
\hline
\end{tabular}

Degree FE
Major FE

X

X

Institution*Degree*Major FE

$\mathbf{X}$

X

X

$\mathbf{X}$

$\mathbf{X}$

X

Observations

$120,017 \quad 120,017 \quad 120,017$

72,176

72,176

72,176

0.13

0.13

0.14

0.19

Notes: Standard errors in parentheses.

0.10

effects. Degree fixed effects are included for three-year "tecnológico" degrees and two-year "técnico profesional" degrees. 
Table 7. Effects of Online Programs on Writing Test Scores, Techical Programs, Saber TyT

Writing Exam Z-Score

\begin{tabular}{|c|c|c|c|c|c|c|c|c|}
\hline \multicolumn{3}{|c|}{ Full Sample } & \multicolumn{3}{|c|}{ Private Institutions } & \multicolumn{3}{|c|}{ Public Institution (SENA) } \\
\hline$(1)$ & $(2)$ & $(3)$ & $(4)$ & (5) & $(6)$ & $(7)$ & $(8)$ & $(9)$ \\
\hline $\begin{array}{c}-0.069^{* * *} \\
(0.007)\end{array}$ & $\begin{array}{c}-0.086^{* * *} \\
(0.007)\end{array}$ & $\begin{array}{c}0.011 \\
(0.010)\end{array}$ & $\begin{array}{l}-0.007 \\
(0.013)\end{array}$ & $\begin{array}{c}-0.055^{* * *} \\
(0.013)\end{array}$ & $\begin{array}{c}-0.036^{*} \\
(0.022)\end{array}$ & $\begin{array}{l}0.025^{* *} \\
(0.011)\end{array}$ & $\begin{array}{c}0.033^{* * *} \\
(0.011)\end{array}$ & $\begin{array}{c}0.032^{* * *} \\
(0.011)\end{array}$ \\
\hline
\end{tabular}

Degree FE

$\mathbf{X}$

$\mathbf{X}$

$\mathbf{X}$

Major FE

$\mathbf{X}$

$\mathbf{X}$

$\mathbf{X}$

$\mathbf{X}$

Institution*Degree*Major FE

$\mathbf{X}$

$\mathbf{x}$

Observations

$116,965 \quad 116,965 \quad 116,965$

70,323

70,323

70,323

0.09

46,642

0.06

46,642

0.07

46,642

Notes: Standart

$0.05 \quad 0.07$

0.06

0.06

to equatio

effects. Degree fixed effects are included for three-year "tecnológico" degrees and two-year "técnico profesional" degrees. 
Table 8. Impact of Online Programs on Test Scores, by Technical Field of Study, Saber TyT

\begin{tabular}{|c|c|c|c|c|c|c|}
\hline \multirow[b]{3}{*}{ A. Health } & \multicolumn{6}{|c|}{ Exam Z-Score } \\
\hline & \multicolumn{2}{|c|}{ Quant } & \multicolumn{2}{|c|}{ Reading } & \multicolumn{2}{|c|}{ Writing } \\
\hline & $(1)$ & $(2)$ & (3) & $(4)$ & (5) & $(6)$ \\
\hline Online & $\begin{array}{l}-0.036 \\
(0.039)\end{array}$ & $\begin{array}{c}0.050 \\
(0.043)\end{array}$ & $\begin{array}{c}-0.060^{* *} \\
(0.030)\end{array}$ & $\begin{array}{c}0.054 \\
(0.044)\end{array}$ & $\begin{array}{l}-0.033 \\
(0.039)\end{array}$ & $\begin{array}{c}0.093^{*} \\
(0.049)\end{array}$ \\
\hline $\begin{array}{l}\text { Degree FE } \\
\text { Institution*Degree }\end{array}$ & $\mathrm{X}$ & $\mathrm{X}$ & $\mathrm{X}$ & $\mathrm{X}$ & $\mathrm{X}$ & $\mathrm{X}$ \\
\hline $\begin{array}{l}\text { Observations } \\
\text { R-squared }\end{array}$ & $\begin{array}{c}9,553 \\
0.25\end{array}$ & $\begin{array}{c}9,553 \\
0.29\end{array}$ & $\begin{array}{c}9,553 \\
0.16\end{array}$ & $\begin{array}{c}9,553 \\
0.20\end{array}$ & $\begin{array}{c}9,223 \\
0.14\end{array}$ & $\begin{array}{c}9,223 \\
0.16\end{array}$ \\
\hline
\end{tabular}

B. Art, Design \& Communication

\begin{tabular}{|c|c|c|c|c|c|c|}
\hline Online & $\begin{array}{l}-0.028 \\
(0.038)\end{array}$ & $\begin{array}{l}0.165^{* *} \\
(0.076)\end{array}$ & $\begin{array}{c}0.047 \\
(0.040)\end{array}$ & $\begin{array}{c}0.401^{* * *} \\
(0.074)\end{array}$ & $\begin{array}{c}-0.104^{* * *} \\
(0.039)\end{array}$ & $\begin{array}{c}0.132^{*} \\
(0.073)\end{array}$ \\
\hline $\begin{array}{l}\text { Degree FE } \\
\text { Institution*Degree }\end{array}$ & $\mathrm{X}$ & $\mathrm{X}$ & $\mathrm{x}$ & $\mathrm{X}$ & $\mathrm{X}$ & $\mathrm{X}$ \\
\hline $\begin{array}{l}\text { Observations } \\
\text { R-squared }\end{array}$ & $\begin{array}{c}9,062 \\
0.17\end{array}$ & $\begin{array}{c}9,062 \\
0.20\end{array}$ & $\begin{array}{c}9,062 \\
0.13\end{array}$ & $\begin{array}{c}9,062 \\
0.17\end{array}$ & $\begin{array}{c}8,883 \\
0.12\end{array}$ & $\begin{array}{c}8,883 \\
0.15\end{array}$ \\
\hline \multicolumn{7}{|l|}{ C. Engineering } \\
\hline Online & $\begin{array}{c}-0.132 * * * \\
(0.016)\end{array}$ & $\begin{array}{c}0.155^{* * *} \\
(0.023)\end{array}$ & $\begin{array}{c}-0.089^{* * *} \\
(0.017)\end{array}$ & $\begin{array}{c}0.144^{* * *} \\
(0.024)\end{array}$ & $\begin{array}{c}-0.131^{* * *} \\
(0.016)\end{array}$ & $\begin{array}{c}0.097^{* * *} \\
(0.024)\end{array}$ \\
\hline $\begin{array}{l}\text { Degree FE } \\
\text { Institution*Degree }\end{array}$ & $\mathrm{X}$ & $\mathrm{X}$ & $\mathrm{X}$ & $\mathrm{X}$ & $\mathrm{X}$ & $\mathrm{X}$ \\
\hline $\begin{array}{l}\text { Observations } \\
\text { R-squared }\end{array}$ & $\begin{array}{c}26,543 \\
0.18\end{array}$ & $\begin{array}{c}26,543 \\
0.23\end{array}$ & $\begin{array}{c}26,543 \\
0.13\end{array}$ & $\begin{array}{c}26,543 \\
0.17\end{array}$ & $\begin{array}{c}25,871 \\
0.10\end{array}$ & $\begin{array}{c}25,871 \\
0.13\end{array}$ \\
\hline \multicolumn{7}{|l|}{ D. Tourism } \\
\hline Online & $\begin{array}{l}-0.025^{* *} \\
(0.010)\end{array}$ & $\begin{array}{c}0.121^{* * *} \\
(0.013)\end{array}$ & $\begin{array}{c}-0.024^{* *} \\
(0.011)\end{array}$ & $\begin{array}{c}0.088^{* * *} \\
(0.014)\end{array}$ & $\begin{array}{c}-0.075^{* * *} \\
(0.010)\end{array}$ & $\begin{array}{l}-0.004 \\
(0.014)\end{array}$ \\
\hline $\begin{array}{l}\text { Degree FE } \\
\text { Institution*Degree }\end{array}$ & $\mathrm{X}$ & $\mathrm{X}$ & $\mathrm{X}$ & $\mathrm{X}$ & $\mathrm{X}$ & $\mathrm{X}$ \\
\hline Observations & 51,850 & 51,850 & 51,850 & 51,850 & 50,782 & 50,782 \\
\hline R-squared & 0.10 & 0.13 & 0.08 & 0.10 & 0.06 & 0.07 \\
\hline
\end{tabular}

Notes: Standard errors in parentheses. ${ }^{* * *} \mathrm{p}<0.01,{ }^{* *} \mathrm{p}<0.05,{ }^{*} \mathrm{p}<0.1$. Models estimated according to equation (2), including semester and municipality fixed effects. Degree fixed effects are included for three-year "tecnológico" degrees and two-year "técnico profesional" degrees. 
Table 9. Heterogeneity of Effects of Online Programs on Quantitative Test Scores, Saber TyT

\begin{tabular}{|c|c|c|}
\hline \multicolumn{3}{|c|}{ Quantitative Exam Z-Score } \\
\hline All & Private & Public (SENA) \\
\hline (1) & (2) & (3) \\
\hline
\end{tabular}

\begin{tabular}{|c|c|c|c|}
\hline \multicolumn{4}{|l|}{ A. Gender } \\
\hline \multicolumn{4}{|l|}{ Female } \\
\hline \multirow[t]{2}{*}{ Online } & $0.120^{* * *}$ & -0.005 & $0.174^{* * *}$ \\
\hline & $(0.012)$ & $(0.024)$ & $(0.014)$ \\
\hline Observations & 62,229 & 35,882 & 26,347 \\
\hline \multicolumn{4}{|l|}{ Male } \\
\hline \multirow[t]{2}{*}{ Online } & $0.068^{* * *}$ & $-0.065^{* *}$ & $0.103^{* * *}$ \\
\hline & $(0.014)$ & $(0.033)$ & $(0.017)$ \\
\hline Observations & 57,788 & 36,294 & 21,494 \\
\hline \multicolumn{4}{|l|}{ B. Age } \\
\hline \multicolumn{4}{|l|}{ Age $<20$} \\
\hline \multirow[t]{2}{*}{ Online } & $0.0900^{* *}$ & 0.011 & $0.100^{* * *}$ \\
\hline & $(0.036)$ & $(0.149)$ & $(0.039)$ \\
\hline Observations & 8,603 & 3,640 & 4,963 \\
\hline \multicolumn{4}{|l|}{ Age $20-25$} \\
\hline \multirow[t]{2}{*}{ Online } & $0.121^{* * *}$ & -0.019 & $0.174^{* * *}$ \\
\hline & $(0.011)$ & $(0.023)$ & $(0.013)$ \\
\hline Observations & 92,216 & 56,372 & 35,844 \\
\hline \multicolumn{4}{|l|}{ Age 25 - 30} \\
\hline \multirow[t]{2}{*}{ Online } & $0.121^{* * *}$ & 0.068 & $0.159^{* * *}$ \\
\hline & $(0.025)$ & $(0.047)$ & $(0.032)$ \\
\hline Observations & 16,823 & 10,841 & 5,982 \\
\hline \multicolumn{4}{|l|}{ Age $>30$} \\
\hline \multirow[t]{2}{*}{ Online } & -0.020 & -0.161 & -0.017 \\
\hline & $(0.085)$ & $(0.198)$ & $(0.056)$ \\
\hline Observations & 2,369 & 1,318 & 2,369 \\
\hline Institution*Degree*Major FE & $\mathbf{X}$ & $\mathbf{X}$ & $\mathbf{X}$ \\
\hline
\end{tabular}

Notes: Standard errors in parentheses. ${ }^{* * *} \mathrm{p}<0.01,{ }^{* *} \mathrm{p}<0.05,{ }^{*} \mathrm{p}<0.1$. Models estimated according to equation (2), including semester and municipality fixed effects. Degree fixed effects are included for three-year "tecnológico" degrees and two-year "técnico profesional" degrees. 
Table 10. Oster Test for Selection on Unobservables, Saber TyT

\begin{tabular}{lccc} 
& $\begin{array}{c}\text { Uncontrolled Effect } \\
{[\text { r-squared }]}\end{array}$ & $\begin{array}{c}\text { Controlled Effect } \\
{[\text { r-squared }]}\end{array}$ & $\delta$ \\
\hline A. All Institutions & 0.041 & 0.115 & -33.720 \\
Quantitative & {$[0.000]$} & {$[0.198]$} & \\
\multirow{2}{*}{ Reading } & -0.011 & 0.083 & -3.045 \\
& {$[0.000]$} & {$[0.129]$} & \\
Writing & -0.096 & 0.011 & -0.169 \\
& {$[0.002]$} & {$[0.071]$} & \\
\hline B. Private Institutions & & & \\
Quantitative & -0.080 & -0.021 & 0.303 \\
& {$[0.001]$} & {$[0.276]$} & \\
Reading & -0.078 & -0.027 & 0.374 \\
& {$[0.001]$} & {$[0.187]$} & \\
Writing & -0.044 & -0.036 & 1.210 \\
& {$[0.000]$} & {$[0.088]$} & \\
\hline C. Public Institution (SENA Only) & 0.166 & 3.270 \\
Quantitative & 0.256 & {$[0.134]$} & \\
& {$[0.010]$} & 0.127 & 5.100 \\
Reading & 0.163 & {$[0.087]$} & \\
& {$[0.005]$} & 0.032 & -3.137 \\
Writing & -0.018 & {$[0.068]$} & \\
& {$[0.000]$} & & \\
\hline
\end{tabular}

Notes: Analyses conducted following Oster (2017) using Stata's PSACALC command with $\mathrm{Rmax}=1.3^{*} \mathrm{R}$-squared of the controlled regression and beta $=0$. Delta is the coefficient of proportionality, as described in equation (3). Outcomes correspond to zscores of the Saber TyT exam. 
Table 11. Instrumental Variables Estimates of the Impact of Online Programs on Test Scores, Technical Programs, Saber TyT

\begin{tabular}{|c|c|c|c|c|}
\hline & \multirow{3}{*}{$\begin{array}{c}\text { First Stage } \\
\text { Online } \\
(1)\end{array}$} & \multicolumn{3}{|c|}{ Second Stage: Exam Z-Score } \\
\hline & & \multirow{3}{*}{$\begin{array}{c}\text { Quant } \\
(2)\end{array}$} & \multirow{2}{*}{$\begin{array}{c}\text { Reading } \\
(3)\end{array}$} & \multirow{2}{*}{$\frac{\text { Writing }}{(4)}$} \\
\hline & & & & \\
\hline \multicolumn{4}{|l|}{ A. All Institutions } & \\
\hline Internet Speed & $\begin{array}{c}-2.48 \mathrm{e}-05^{* * *} \\
(2.10 \mathrm{e}-06)\end{array}$ & & & \\
\hline Online & & $\begin{array}{c}-0.663^{* * *} \\
(0.157)\end{array}$ & $\begin{array}{c}-0.873^{* * *} \\
(0.175)\end{array}$ & $\begin{array}{c}0.120 \\
(0.185)\end{array}$ \\
\hline Observations & 46,759 & 46,759 & 46,759 & 45,686 \\
\hline F-Stat & 134.022 & & & \\
\hline \multicolumn{5}{|l|}{ B. Private Institutions } \\
\hline Internet Speed & $\begin{array}{c}-0.47^{* * *} \\
(0.117)\end{array}$ & & & \\
\hline Online & & $\begin{array}{c}-0.466^{* * *} \\
(0.117)\end{array}$ & $\begin{array}{c}-0.545^{* * *} \\
(0.128)\end{array}$ & $\begin{array}{c}-0.072 \\
(0.140)\end{array}$ \\
\hline Observations & 26,305 & 26,305 & 26,305 & 25,697 \\
\hline F-Stat & 472.663 & & & \\
\hline \multicolumn{5}{|c|}{ C. Public Institution (SENA Only) } \\
\hline Internet Speed & $\begin{array}{c}4.263 \\
(5.046)\end{array}$ & & & \\
\hline Online & & $\begin{array}{c}4.263 \\
(5.050)\end{array}$ & $\begin{array}{c}7.840 \\
(8.716)\end{array}$ & $\begin{array}{c}-3.183 \\
(3.775)\end{array}$ \\
\hline Observations & 20,454 & 20,454 & 20,454 & 19,989 \\
\hline F-Stat & 1.550 & & & \\
\hline P-value of SENA-No SENA & 0.453 & 0.453 & 0.350 & 0.101 \\
\hline
\end{tabular}

Notes: The instrument is Internet download speed in the individual's city and socioeconomic status in 11 th grade, measured in $\mathrm{MHz}$ divided by 1,000. All models include controls for 11th grade test scores, age, sex, indicators for socioeconomic status, semester-year, and municipality fixed effects according to equations (4) and (5). 


\section{APPENDIX TABLES}

\section{Appendix Table A1. Higher Education Institution with Online}

Students taking Saber TyT (2016-2017)

\begin{tabular}{lcc} 
No. of Online Students & No. of Institutions & $\%$ \\
\hline & & \\
Less than 25 & 23 & $0.6 \%$ \\
$25-50$ & 10 & $0.8 \%$ \\
$50-100$ & 7 & $1.0 \%$ \\
$100-200$ & 8 & $2.8 \%$ \\
$200-300$ & 4 & $2.3 \%$ \\
$300-400$ & 4 & $3.0 \%$ \\
$400-500$ & 1 & $1.1 \%$ \\
$500-1000$ & 3 & $4.2 \%$ \\
$1,000-3,000$ & 1 & $6.7 \%$ \\
$3,000-30,000$ & 0 & $0.0 \%$ \\
More than 30,000 (SENA) & 1 & $77.5 \%$ \\
Total & 62 & $100.0 \%$ \\
\hline
\end{tabular}

Source: Saber TyT 2016-17. 


\section{Appendix Table A2. Probability of Attending Online, Technical and Bachelor's Degree Students, Saber TyT and Saber Pro}

\begin{tabular}{|c|c|c|c|c|}
\hline & \multicolumn{3}{|c|}{$\begin{array}{c}\text { Technical Programs } \\
\text { Saber TyT }\end{array}$} & \multirow{3}{*}{$\begin{array}{l}\begin{array}{c}\text { Bachelor's Degre } \\
\text { Saber Pro }\end{array} \\
\text { Full Sample } \\
(4)\end{array}$} \\
\hline & Full Sample & $\begin{array}{c}\text { Private } \\
\text { Institutions }\end{array}$ & Only SENA & \\
\hline & $(1)$ & $(2)$ & (3) & \\
\hline Female & $\begin{array}{l}0.224^{* * *} \\
(0.008)\end{array}$ & $\begin{array}{l}0.429^{* * *} \\
(0.013)\end{array}$ & $\begin{array}{l}0.094^{* * *} \\
(0.013)\end{array}$ & $\begin{array}{c}0.230^{* * *} \\
(0.008)\end{array}$ \\
\hline Age at College Exit & $\begin{array}{c}0.045^{* * *} \\
(0.00)\end{array}$ & $\begin{array}{c}0.059^{* * *} \\
(0.003)\end{array}$ & $\begin{array}{l}-0.020^{* * *} \\
(0.002)\end{array}$ & $\begin{array}{c}0.078^{* * *} \\
(0.002)\end{array}$ \\
\hline Social Stratification - 11th grade & $\begin{array}{l}-0.180^{* * *} \\
(0.005)\end{array}$ & $\begin{array}{l}-0.236^{* * *} \\
(0.009)\end{array}$ & $\begin{array}{l}-0.063^{* * *} \\
(0.009)\end{array}$ & $\begin{array}{l}-0.303^{* * *} \\
(0.005)\end{array}$ \\
\hline Home Internet - 11 th grade & $\begin{array}{l}-0.222^{* * *} \\
(0.009)\end{array}$ & $\begin{array}{c}-0.319^{* * *} \\
(0.014)\end{array}$ & $\begin{array}{l}-0.009 \\
(0.014)\end{array}$ & $\begin{array}{l}-0.351^{* * *} \\
(0.008)\end{array}$ \\
\hline Technical High School & $\begin{array}{l}0.070^{* * *} \\
(0.008)\end{array}$ & $\begin{array}{c}0.014 \\
(0.013)\end{array}$ & $\begin{array}{l}0.146^{* * *} \\
(0.013)\end{array}$ & \\
\hline Math Score - Saber11 & $\begin{array}{l}-0.037^{* * *} \\
(0.005)\end{array}$ & $\begin{array}{l}-0.013 \\
(0.008)\end{array}$ & $\begin{array}{l}-0.006 \\
(0.008)\end{array}$ & $\begin{array}{l}-0.119^{* * *} \\
(0.005)\end{array}$ \\
\hline Spanish Score - Saber11 & $\begin{array}{c}-0.023^{* * *} \\
(0.005)\end{array}$ & $\begin{array}{c}-0.052^{* * *} \\
(0.008)\end{array}$ & $\begin{array}{l}0.0004 \\
(0.008)\end{array}$ & $\begin{array}{c}-0.093^{* * *} \\
(0.005)\end{array}$ \\
\hline Social Science Score - Saber11 & $\begin{array}{l}-0.019 * * * \\
(0.005)\end{array}$ & $\begin{array}{l}-0.003 \\
(0.009)\end{array}$ & $\begin{array}{l}-0.014 \\
(0.009)\end{array}$ & $\begin{array}{l}-0.114^{* * *} \\
(0.005)\end{array}$ \\
\hline Philosophy Score - Saber11 & $\begin{array}{l}-0.007 \\
(0.005)\end{array}$ & $\begin{array}{l}-0.007 \\
(0.008)\end{array}$ & $\begin{array}{l}-0.009 \\
(0.008)\end{array}$ & $\begin{array}{l}-0.050^{* * *} \\
(0.004)\end{array}$ \\
\hline Biology Score - Saber11 & $\begin{array}{l}-0.018^{* * *} \\
(0.005)\end{array}$ & $\begin{array}{l}-0.026^{* * *} \\
(0.008)\end{array}$ & $\begin{array}{l}-0.015^{*} \\
(0.008)\end{array}$ & $\begin{array}{l}-0.065^{* * *} \\
(0.005)\end{array}$ \\
\hline Chemistry Score - Saber11 & $\begin{array}{c}-0.014^{* * *} \\
(0.005)\end{array}$ & $\begin{array}{c}0.002 \\
(0.008)\end{array}$ & $\begin{array}{l}0.020^{* *} \\
(0.008)\end{array}$ & $\begin{array}{c}-0.076^{* * *} \\
(0.005)\end{array}$ \\
\hline Physics Score - Saber11 & $\begin{array}{l}-0.020^{* * *} \\
(0.005)\end{array}$ & $\begin{array}{l}-0.010 \\
(0.007)\end{array}$ & $\begin{array}{l}-0.012^{*} \\
(0.007)\end{array}$ & $\begin{array}{l}-0.049^{* * *} \\
(0.004)\end{array}$ \\
\hline English Score - Saber11 & $\begin{array}{l}-0.044^{* * *} \\
(0.005)\end{array}$ & $\begin{array}{l}-0.052^{* * *} \\
(0.008)\end{array}$ & $\begin{array}{c}0.004 \\
(0.008)\end{array}$ & \\
\hline Observations & 120,021 & 72,179 & 47,842 & 387,223 \\
\hline
\end{tabular}

Notes: Standard deviation in parentheses. Samples include only students who could be merged with 11th-grade test scores data in Saber 11 and without missing values in the variables of interest. Social stratification ranges from 1 to 6 , with 6 as the highest-income neighborhoods. Test scores are z-scores. All specifications are probit estimates of the propensity to take online coursework according to equation (1). 


\section{Appendix Table A3. Coarsened Exact Matching, Summary Statistics}

\begin{tabular}{|c|c|c|c|c|}
\hline \multirow[b]{3}{*}{ Variable means (st. dev) } & \multicolumn{4}{|c|}{ Saber TyT - Technical Programs } \\
\hline & Online & $\begin{array}{c}\text { On- } \\
\text { campus }\end{array}$ & $\begin{array}{l}\text { Online } \\
\text { (CEM) }\end{array}$ & $\begin{array}{c}\text { On- } \\
\text { campus } \\
\text { (CEM) }\end{array}$ \\
\hline & (1) & $(2)$ & (3) & (4) \\
\hline Female & $\begin{array}{c}0.500 \\
(0.500)\end{array}$ & $\begin{array}{c}0.585 \\
(0.493)\end{array}$ & $\begin{array}{c}0.585 \\
(0.493)\end{array}$ & $\begin{array}{c}0.585 \\
(0.493)\end{array}$ \\
\hline Age & $\begin{array}{l}21.619 \\
(2.949)\end{array}$ & $\begin{array}{l}21.575 \\
(3.448)\end{array}$ & $\begin{array}{l}21.506 \\
(3.068)\end{array}$ & $\begin{array}{c}21.476 \\
(3.162)\end{array}$ \\
\hline Social Stratification - 11th grade & $\begin{array}{c}1.958 \\
(0.831)\end{array}$ & $\begin{array}{c}1.747 \\
(0.749)\end{array}$ & $\begin{array}{c}1.741 \\
(0.737)\end{array}$ & $\begin{array}{c}1.741 \\
(0.737)\end{array}$ \\
\hline Home Internet - 11th grade & $\begin{array}{c}0.513 \\
(0.500)\end{array}$ & $\begin{array}{c}0.416 \\
(0.493)\end{array}$ & $\begin{array}{c}0.472 \\
(0.499)\end{array}$ & $\begin{array}{c}0.416 \\
(0.493)\end{array}$ \\
\hline Technical High School & $\begin{array}{c}0.322 \\
(0.467)\end{array}$ & $\begin{array}{c}0.380 \\
(0.485)\end{array}$ & $\begin{array}{c}0.340 \\
(0.474)\end{array}$ & $\begin{array}{c}0.382 \\
(0.486)\end{array}$ \\
\hline Math Score - Saber 11 & $\begin{array}{c}0.104 \\
(0.860)\end{array}$ & $\begin{array}{l}-0.016 \\
(0.834)\end{array}$ & $\begin{array}{c}0.084 \\
(0.855)\end{array}$ & $\begin{array}{l}-0.014 \\
(0.833)\end{array}$ \\
\hline Spanish Score - Saber11 & $\begin{array}{c}0.120 \\
(0.882)\end{array}$ & $\begin{array}{l}-0.021 \\
(0.875)\end{array}$ & $\begin{array}{c}0.105 \\
(0.873)\end{array}$ & $\begin{array}{l}-0.020 \\
(0.875)\end{array}$ \\
\hline Social Science Score - Saber11 & $\begin{array}{c}0.117 \\
(0.883)\end{array}$ & $\begin{array}{l}-0.025 \\
(0.865)\end{array}$ & $\begin{array}{c}0.095 \\
(0.875)\end{array}$ & $\begin{array}{l}-0.026 \\
(0.864)\end{array}$ \\
\hline Philosophy Score - Saber11 & $\begin{array}{c}0.087 \\
(0.919)\end{array}$ & $\begin{array}{l}-0.017 \\
(0.910)\end{array}$ & $\begin{array}{c}0.082 \\
(0.913)\end{array}$ & $\begin{array}{l}-0.016 \\
(0.909)\end{array}$ \\
\hline Biology Score - Saber11 & $\begin{array}{c}0.114 \\
(0.891)\end{array}$ & $\begin{array}{l}-0.029 \\
(0.889)\end{array}$ & $\begin{array}{c}0.094 \\
(0.882)\end{array}$ & $\begin{array}{l}-0.028 \\
(0.888)\end{array}$ \\
\hline Chemistry Score - Saber11 & $\begin{array}{c}0.116 \\
(0.887)\end{array}$ & $\begin{array}{l}-0.017 \\
(0.856)\end{array}$ & $\begin{array}{c}0.112 \\
(0.873)\end{array}$ & $\begin{array}{l}-0.015 \\
(0.855)\end{array}$ \\
\hline Physics Score - Saber11 & $\begin{array}{c}0.097 \\
(0.926)\end{array}$ & $\begin{array}{l}-0.025 \\
(0.907)\end{array}$ & $\begin{array}{c}0.089 \\
(0.925)\end{array}$ & $\begin{array}{c}-0.024 \\
(0.906)\end{array}$ \\
\hline English Score - Saber11 & $\begin{array}{c}0.016 \\
(0.911)\end{array}$ & $\begin{array}{c}-0.066 \\
(0.841)\end{array}$ & $\begin{array}{c}-0.021 \\
(0.873)\end{array}$ & $\begin{array}{l}-0.065 \\
(0.838)\end{array}$ \\
\hline Observations & 114,444 & 93,732 & 96,881 & 92,692 \\
\hline
\end{tabular}

Notes: Standard deviation in parentheses. Samples include only students who could be merged with 11th-grade test scores data in Saber 11 and without missing values in the variables of interest. Social stratification ranges from 1 to 6 , with 6 as the highest-income neighborhoods. CEM was implemented based on bins for sex, age $(<20,20-25,25-30,30-40$, $>40$ ), social stratification (1-6), major, year, and the five biggest municipalities in the country (Bogotá, Medellín, Cali, Barranquilla, Cartagena, and rest of the country). †Adequate balance $<0.1$; Acceptable Balance 0.1-0.2; Imbalance $>0.2$. 


\section{Appendix Table A4. Coarsened Exact Matching, Effects of Online Programs on Quantitative Test Scores, Saber TyT}

Quantitative Exam Z-Score

\begin{tabular}{|c|c|c|c|c|c|c|c|c|c|}
\hline & \multicolumn{3}{|c|}{ Full Sample } & \multicolumn{3}{|c|}{ Private Institutions } & \multicolumn{3}{|c|}{ Public Institutions (SENA Only) } \\
\hline & $(1)$ & $(2)$ & $(3)$ & $(4)$ & $(5)$ & $(6)$ & (7) & $(8)$ & $(9)$ \\
\hline Online & $\begin{array}{c}-0.159^{* * *} \\
(0.006)\end{array}$ & $\begin{array}{c}-0.140^{* * *} \\
(0.006)\end{array}$ & $\begin{array}{c}0.027^{* * *} \\
(0.007)\end{array}$ & $\begin{array}{c}-0.192^{* * *} \\
(0.012)\end{array}$ & $\begin{array}{c}-0.133^{* * *} \\
(0.012)\end{array}$ & $\begin{array}{c}-0.120^{* * *} \\
(0.021)\end{array}$ & $\begin{array}{c}0.052^{* * *} \\
(0.008)\end{array}$ & $\begin{array}{c}0.055^{* * *} \\
(0.008)\end{array}$ & $\begin{array}{c}0.055^{* * *} \\
(0.008)\end{array}$ \\
\hline
\end{tabular}

Degree FE

$\mathbf{X}$

$\mathbf{X}$

Major FE

$\mathbf{X}$

$\mathbf{X}$

$\mathbf{X}$

HEI*Degree*Major FE

$\mathbf{X}$

$\mathbf{X}$

$\mathbf{X}$

\begin{tabular}{lccccccccc} 
Observations & 189,536 & 189,536 & 189,536 & 76,474 & 76,474 & 76,474 & 113,062 & 113,062 & 113,062 \\
R-squared & 0.12 & 0.14 & 0.18 & 0.17 & 0.20 & 0.26 & 0.12 & 0.13 & 0.13 \\
\hline
\end{tabular}

Notes: Standard errors in parentheses. ${ }^{* * *} \mathrm{p}<0.01,{ }^{* *} \mathrm{p}<0.05,{ }^{*} \mathrm{p}<0.1$. Models estimated according to equation (2), including semester and municipality fixed effects. HEI is "higher education institution." Degree fixed effects are included for three-year "tecnológico" degrees and two-year "técnico profesional" degrees. All models include semester-year and municipality fixed effects. CEM was implemented based on bins for sex, age (<20, 20-25, 25$30,30-40,>40$ ), social stratification (1-6), major, year, and the five biggest municipalities in the country (Bogotá, Medellín, Cali, Barranquilla, Cartagena, and rest of the country). $\nmid$ Adequate balance $<0.1$; Acceptable Balance 0.1-0.2; Imbalance $>0.2$. 
Appendix Table A5. Coarsened Exact Matching, Effects of Online Programs on Reading Test Scores, Saber Ty5

Reading Exam Z-Score

\begin{tabular}{|c|c|c|c|c|c|c|c|c|}
\hline \multicolumn{3}{|c|}{ Full Sample } & \multicolumn{3}{|c|}{ Private Institutions } & \multicolumn{3}{|c|}{ Public Institutions (SENA Only) } \\
\hline$(1)$ & $(2)$ & $(3)$ & $(4)$ & (5) & $(6)$ & $(7)$ & $(8)$ & $(9)$ \\
\hline $\begin{array}{c}-0.144^{* * *} \\
(0.006)\end{array}$ & $\begin{array}{c}-0.133^{* * *} \\
(0.006)\end{array}$ & $\begin{array}{c}0.006 \\
(0.008)\end{array}$ & $\begin{array}{c}-0.150^{* * *} \\
(0.013)\end{array}$ & $\begin{array}{c}-0.123^{* * *} \\
(0.013)\end{array}$ & $\begin{array}{c}-0.113^{* * *} \\
(0.022)\end{array}$ & $\begin{array}{c}0.028^{* * *} \\
(0.008)\end{array}$ & $\begin{array}{c}0.028^{* * *} \\
(0.008)\end{array}$ & $\begin{array}{c}0.029^{* * *} \\
(0.008)\end{array}$ \\
\hline \multirow[t]{2}{*}{$\mathbf{X}$} & & & $\mathbf{X}$ & & & $\mathbf{X}$ & & \\
\hline & $\mathbf{X}$ & & & $\mathbf{X}$ & & & $\mathbf{X}$ & \\
\hline $\mathrm{FE}$ & & $\mathbf{X}$ & & & $\mathbf{X}$ & & & $\mathbf{X}$ \\
\hline 189,536 & 189,536 & 189,536 & 76,474 & 76,474 & 76,474 & 113,062 & 113,062 & 113,062 \\
\hline 0.09 & 0.10 & 0.13 & 0.13 & 0.13 & 0.19 & 0.09 & 0.09 & 0.09 \\
\hline
\end{tabular}

$\begin{array}{llllllll}\text { R-squared } & 0.09 & 0.10 & 0.13 & 0.13 & 0.13 & 0.19 & 0.09 \\ \text { Notes: Standard errors in parentheses. }{ }^{* * *} \mathrm{p}<0.01,{ }^{* *} \mathrm{p}<0.05,{ }^{*} \mathrm{p}<0.1 \text {. Models estimated according to equation (2), including semester and municipality }\end{array}$ fixed effects. HEI is "higher education institution." Degree fixed effects are included for three-year "tecnológico" degrees and two-year "técnico profesional" degrees. All models include semester-year and municipality fixed effects. CEM was implemented based on bins for sex, age $(<20,20-25,25-$ $30,30-40,>40$ ), social stratification (1-6), major, year, and the five biggest municipalities in the country (Bogotá, Medellín, Cali, Barranquilla, Cartagena, and rest of the country). †Adequate balance $<0.1$; Acceptable Balance 0.1-0.2; Imbalance $>0.2$. 


\section{Appendix Table A6. Coarsened Exact Matching, Effects of Online Programs on Writing Test Scores, Saber TyT}

\section{Writing Exam Z-Score}

\begin{tabular}{|c|c|c|c|c|c|c|c|c|c|}
\hline & \multicolumn{3}{|c|}{ Full Sample } & \multicolumn{3}{|c|}{ Private Institutions } & \multicolumn{3}{|c|}{ Public Institutions (SENA Only) } \\
\hline & $(1)$ & $(2)$ & (3) & $(4)$ & $(5)$ & $(6)$ & $(7)$ & $(8)$ & $(9)$ \\
\hline Online & $\begin{array}{c}-0.143^{* * *} \\
(0.006)\end{array}$ & $\begin{array}{c}-0.141^{* * *} \\
(0.006)\end{array}$ & $\begin{array}{c}-0.017^{* *} \\
(0.008)\end{array}$ & $\begin{array}{c}-0.084^{* * *} \\
(0.013)\end{array}$ & $\begin{array}{c}-0.097^{* * *} \\
(0.013)\end{array}$ & $\begin{array}{c}-0.083^{* * *} \\
(0.022)\end{array}$ & $\begin{array}{l}-0.010 \\
(0.009)\end{array}$ & $\begin{array}{c}-0.004 \\
(0.009)\end{array}$ & $\begin{array}{l}-0.003 \\
(0.009)\end{array}$ \\
\hline
\end{tabular}

Degree FE

$\mathbf{X}$

$\mathbf{X}$

Major FE

HEI*Degree*Major FE

Observations

$184,710 \quad 184,710 \quad 184,710$

X

X

X

R-squared

0.04

0.05

0.07

74,578

0.07

74,578

0.07

X

X

Notes: Standard errors in parentheses. ${ }^{* *} \mathrm{p}<0.01,{ }^{* *} \mathrm{p}<0.05,{ }^{*} \mathrm{p}<0.1$. Models estimated according to equation (2), including semester and municipality fixed effects. HEI is "higher education institution." Degree fixed effects are included for three-year "tecnológico" degrees and two-year "técnico profesional" degrees. All models include semester-year and municipality fixed effects. CEM was implemented based on bins for sex, age $(<20,20-25,25-30$, $30-40,>40$ ), social stratification (1-6), major, year, and the five biggest municipalities in the country (Bogotá, Medellín, Cali, Barranquilla, Cartagena, and rest of the country). $\dagger$ Adequate balance $<0.1$; Acceptable Balance 0.1-0.2; Imbalance $>0.2$. 
Appendix Table A7. Effects of Online Programs by Type of HIE, Techical Programs, Saber TyT

\begin{tabular}{|c|c|c|c|c|c|c|c|c|c|}
\hline & \multicolumn{9}{|c|}{ Exam Z-Score } \\
\hline & \multicolumn{3}{|c|}{ Full Sample } & \multicolumn{3}{|c|}{ Private Institutions } & \multicolumn{3}{|c|}{$\begin{array}{l}\text { Public Institutions } \\
\text { (all including SENA) }\end{array}$} \\
\hline & $(1)$ & $(2)$ & (3) & $(4)$ & (5) & $(6)$ & $(7)$ & $(8)$ & $(9)$ \\
\hline \multicolumn{10}{|c|}{ Panel A. Quantitative Score } \\
\hline Online & $\begin{array}{c}-0.01 \\
(0.006)\end{array}$ & $\begin{array}{c}-0.040^{* * *} \\
(0.006)\end{array}$ & $\begin{array}{c}0.115^{* * *} \\
(0.009)\end{array}$ & $\begin{array}{l}-0.003 \\
(0.016)\end{array}$ & $\begin{array}{l}-0.022 \\
(0.016)\end{array}$ & $\begin{array}{c}0.003 \\
(0.021)\end{array}$ & $\begin{array}{c}0.131^{* * *} \\
(0.010)\end{array}$ & $\begin{array}{c}-0.022^{* *} \\
(0.008)\end{array}$ & $\begin{array}{c}0.147^{* * *} \\
(0.010)\end{array}$ \\
\hline Degree FE & $\mathbf{X}$ & & & $\mathbf{X}$ & & & $\mathbf{X}$ & & \\
\hline Major FE & & $\mathbf{X}$ & & & $\mathbf{X}$ & & & $\mathbf{X}$ & \\
\hline HEI*Degree*Major FE & & & $\mathbf{X}$ & & & $\mathbf{X}$ & & & $\mathbf{X}$ \\
\hline Observations & 120,017 & 120,017 & 120,017 & 43,299 & 43,299 & 43,299 & 76,718 & 76,718 & 76,718 \\
\hline R-squared & 0.13 & 0.16 & 0.20 & 0.17 & 0.18 & 0.22 & 0.18 & 0.17 & 0.20 \\
\hline \multicolumn{10}{|l|}{ Panel B. Reading Score } \\
\hline Online & $\begin{array}{c}-0.017^{* *} \\
(0.007)\end{array}$ & $\begin{array}{c}-0.038^{* * *} \\
(0.007)\end{array}$ & $\begin{array}{c}0.083^{* * *} \\
(0.009)\end{array}$ & $\begin{array}{c}-0.008 \\
(0.017)\end{array}$ & $\begin{array}{c}-0.000 \\
(0.017)\end{array}$ & $\begin{array}{c}-0.012 \\
(0.023)\end{array}$ & $\begin{array}{c}0.095^{* * *} \\
(0.010)\end{array}$ & $\begin{array}{c}-0.032^{* * *} \\
(0.009)\end{array}$ & $\begin{array}{c}0.112^{* * *} \\
(0.010)\end{array}$ \\
\hline Degree FE & $\mathbf{X}$ & & & $\mathbf{x}$ & & & $\mathbf{X}$ & & \\
\hline Major FE & & $\mathbf{X}$ & & & $\mathbf{X}$ & & & $\mathbf{X}$ & \\
\hline HEI*Degree*Major FE & & & $\mathbf{X}$ & & & $\mathbf{x}$ & & & $\mathbf{X}$ \\
\hline Observations & 120,017 & 120,017 & 120,017 & 43,299 & 43,299 & 43,299 & 76,718 & 76,718 & 76,718 \\
\hline R-squared & 0.09 & 0.10 & 0.13 & 0.12 & 0.12 & 0.16 & 0.12 & 0.10 & 0.13 \\
\hline \multicolumn{10}{|l|}{ Panel C. Writing Score } \\
\hline Online & $\begin{array}{c}-0.068^{* * *} \\
(0.007)\end{array}$ & $\begin{array}{c}-0.086^{* * *} \\
(0.007)\end{array}$ & $\begin{array}{c}0.011 \\
(0.010)\end{array}$ & $\begin{array}{c}0.008 \\
(0.017)\end{array}$ & $\begin{array}{c}-0.02 \\
(0.017)\end{array}$ & $\begin{array}{c}-0.013 \\
(0.024)\end{array}$ & $\begin{array}{c}0.006 \\
(0.010)\end{array}$ & $\begin{array}{c}-0.078^{* * *} \\
(0.008)\end{array}$ & $\begin{array}{l}0.021^{* *} \\
(0.010)\end{array}$ \\
\hline Degree FE & $\mathbf{X}$ & & & $\mathbf{x}$ & & & $\mathbf{X}$ & & \\
\hline Major FE & & $\mathbf{X}$ & & & $\mathbf{X}$ & & & $\mathbf{X}$ & \\
\hline HEI*Degree*Major FE & & & $\mathbf{X}$ & & & $\mathbf{x}$ & & & $\mathbf{X}$ \\
\hline Observations & 116,965 & 116,965 & 116,965 & 42,321 & 42,321 & 42,321 & 74,644 & 74,644 & 74,644 \\
\hline R-squared & 0.04 & 0.05 & 0.07 & 0.06 & 0.06 & 0.08 & 0.06 & 0.06 & 0.07 \\
\hline
\end{tabular}

Notes: Standard errors in parentheses. ${ }^{* *} \mathrm{p}<0.01,{ }^{* *} \mathrm{p}<0.05, * \mathrm{p}<0.1$. Models estimated according to equation (2), including semester and municipality fixed effects. HEI is "higher education institution." Degree fixed effects are included for three-year "tecnológico" degrees and two-year "técnico profesional" degrees. 
Appendix Table A8. Effects of Online Programs on English Test Scores, Saber TyT

\begin{tabular}{|c|c|c|c|c|c|c|c|c|c|}
\hline & \multicolumn{9}{|c|}{ English Exam Z-Score } \\
\hline & \multicolumn{3}{|c|}{ Full Sample } & \multicolumn{3}{|c|}{ No SENA } & \multicolumn{3}{|c|}{ Only SENA } \\
\hline & $(1)$ & $(2)$ & (3) & $(4)$ & (5) & $(6)$ & (7) & $(8)$ & (9) \\
\hline Online & $\begin{array}{c}-0.136^{* * *} \\
(0.007)\end{array}$ & $\begin{array}{c}-0.103^{* * *} \\
(0.007)\end{array}$ & $\begin{array}{c}0.0757^{* * *} \\
(0.009)\end{array}$ & $\begin{array}{c}-0.235^{* * *} \\
(0.012)\end{array}$ & $\begin{array}{c}-0.174^{* * *} \\
(0.013)\end{array}$ & $\begin{array}{c}-0.101^{* * *} \\
(0.020)\end{array}$ & $\begin{array}{c}0.141^{* * *} \\
(0.011)\end{array}$ & $\begin{array}{c}0.140^{* * *} \\
(0.011)\end{array}$ & $\begin{array}{c}0.140^{* * *} \\
(0.011)\end{array}$ \\
\hline Degree FE & $\mathbf{X}$ & & & $\mathbf{X}$ & & & $\mathbf{X}$ & & \\
\hline Major FE & & $\mathbf{X}$ & & & $\mathbf{X}$ & & & $\mathbf{X}$ & \\
\hline \multicolumn{2}{|c|}{ HEI*Degree*Major FE } & & $\mathbf{X}$ & & & $\mathbf{X}$ & & & $\mathbf{X}$ \\
\hline Observations & 102,944 & 102,110 & 112,442 & 60,085 & 59,253 & 64,779 & 47,663 & 42,857 & 47,663 \\
\hline R-squared & 0.09 & 0.10 & 0.15 & 0.14 & 0.15 & 0.22 & 0.07 & 0.08 & 0.08 \\
\hline
\end{tabular}

Notes: Standard errors in parentheses. ${ }^{* * *} \mathrm{p}<0.01,{ }^{* *} \mathrm{p}<0.05,{ }^{*} \mathrm{p}<0.1$. Models estimated according to equation (2), including semester and municipality fixed effects. HEI is "higher education institution." Degree fixed effects are included for three-year "tecnológico" degrees and two-year "técnico profesional" degrees. 
Appendix Table A9. Effects of Online Programs on Civics Test Scores, Saber TyT

Civility Exam Z-Score

\begin{tabular}{|c|c|c|c|c|c|c|c|c|c|}
\hline & \multicolumn{3}{|c|}{ Full Sample } & \multicolumn{3}{|c|}{ Private Institutions } & \multicolumn{3}{|c|}{ Public Institutions (Only SENA) } \\
\hline & (1) & (2) & (3) & (4) & (5) & (6) & (7) & (8) & (9) \\
\hline Onlil & $\begin{array}{c}-0.041^{* * *} \\
(0.007)\end{array}$ & $\begin{array}{c}-0.024^{* * *} \\
(0.007)\end{array}$ & $\begin{array}{c}0.079^{* * *} \\
(0.009)\end{array}$ & $\begin{array}{l}-0.010 \\
(0.013)\end{array}$ & $\begin{array}{c}0.006 \\
(0.013)\end{array}$ & $\begin{array}{c}0.032 \\
(0.021)\end{array}$ & $\begin{array}{c}0.095^{* * *} \\
(0.011)\end{array}$ & $\begin{array}{c}0.099 * * * \\
(0.012)\end{array}$ & $\begin{array}{c}0.096^{* * *} \\
(0.011)\end{array}$ \\
\hline
\end{tabular}

\begin{tabular}{|c|c|c|c|c|c|c|c|c|c|}
\hline Degree FE & $\mathbf{X}$ & & & $\mathbf{X}$ & & & $\mathbf{X}$ & & \\
\hline Major FE & & $\mathbf{X}$ & & & $\mathbf{X}$ & & & $\mathbf{X}$ & \\
\hline HEI*Degree*N $^{*}$ & FE & & $\mathbf{X}$ & & & $\mathbf{X}$ & & & $\mathbf{X}$ \\
\hline Observations & 102,944 & 102,110 & 112,442 & 60,085 & 59,253 & 0.103 & 47,663 & 42,857 & 47,663 \\
\hline R-squared & 0.08 & 0.09 & 0.11 & 0.11 & 0.11 & -0.36 & 0.09 & 0.09 & 0.09 \\
\hline
\end{tabular}

Notes: Standard errors in parentheses. ${ }^{* * *} \mathrm{p}<0.01,{ }^{* *} \mathrm{p}<0.05,{ }^{*} \mathrm{p}<0.1$. Models estimated according to equation (2), including semester and municipality fixed effects. HEI is "higher education institution." Degree fixed effects are included for three-year "tecnológico" degrees and two-year "técnico profesional" degrees. 


\section{Appendix Table A10. Effects of Online Programs on Health Test Scores, Saber TyT}

Health Promotion and Disease Prevention Exam Z-Score

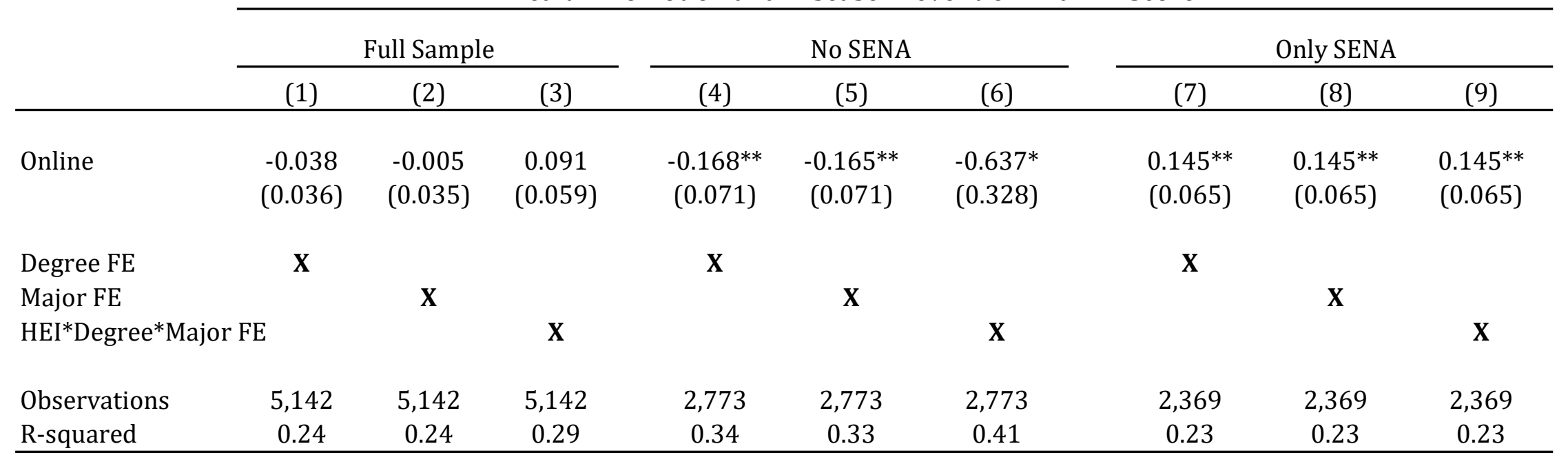

Notes: Standard errors in parentheses. ${ }^{* * *} \mathrm{p}<0.01,{ }^{* *} \mathrm{p}<0.05,{ }^{*} \mathrm{p}<0.1$. Models estimated according to equation (2), including semester and municipality fixed effects. HEI is "higher education institution." Degree fixed effects are included for three-year "tecnológico" degrees and two-year "técnico profesional" degrees. 